\title{
Radon Earthquake Precursor Studies in Iceland
}

\author{
EgILl HaUksSON \\ Department of Geological Sciences and Lamont-Doherty Geological Observatory of Columbia University, Palisades, New York 10964 \\ JOHN G. GODDARD \\ Lamont-Doherty Geological Observatory of Columbia University, Palisades, New York 10964
}

\begin{abstract}
Discrete samples of geothermal water have been collected from a network of nine stations for analysis of radon ( $\left.{ }^{222} \mathrm{Rn}\right)$ content. The sampling network consisted of wells that range in wellhead temperature from $48^{\circ} \mathrm{C}$ to $100^{\circ} \mathrm{C}$, and the depths range from $38 \mathrm{~m}$ to $1338 \mathrm{~m}$. The sampling frequency at most stations was about once per week and twice per week at the station Fludir. The wells are either artesian or pumped more or less continuously. The network covered two regions of transform faulting in Iceland with seven stations in the Southern Iceland Seismic Zone (SISZ) and two stations in northern Iceland in the Tjornes Fracture Zone (TFZ). During 1978 and 1979 several anomalous changes in radon content were observed to precede some of the local earthquakes. Criteria based on tectonic regimes, a magnitudedistance relationship and time clustering were applied to select a set of 23 earthquakes that could be expected to be preceded by a radon anomaly. The magnitude of these earthquakes ranged between 1.0 and 4.3. Each of the 23 earthquakes was within the distance range of one or more stations such that altogether 57 potential observations of possible anomalies were available. The method of analysis applied to the radon and earthquake data consisted of identifying radon anomalies in retrospect, and resulted in nine precursory anomalies, 48 cases of failure to observe an anomaly, and seven false alarms. The probability of observing radon anomalies before earthquakes with magnitudes between 2.0 and 4.3 (the largest event observed) was found to be approximately $65 \%$ based on a weekly sampling rate. In the SISZ, five out of eight earthquakes $(M>2)$ were preceded by an anomaly. In two cases, anomalies were observed at two different stations prior to the same earthquake. The anomalies appeared to occur farther away for larger earthquake magnitude. An aquiclude that divides the SISZ did not seem to affect the occurrence of radon anomalies, but the amplitude of anomalies on the east side were larger than the ones on the west side. The duration times of the anomalies ranged from 17 to 37 days. The large number of failures to observe an anomaly indicated that the occurrence of an anomaly was more strongly dependent on local conditions and earthquake parameters than distance between epicenter and radon station. Some stations also appeared to be less sensitive than others and three stations never showed an anomaly. During periods of bursts in local seismicity, some stations reflected distinctively larger background fluctuations, which hampered the correlation of the seismicity with the radon data. Most of the false alarms were related to disturbances caused by changes in well operation. In the SISZ the high rate of failure to observe an anomaly and the occurrence of false alarms was partly compensated for by operating a dense network of sampling stations. Wells that are utilized at moderate flow rates are less likely to show false alarms than wells utilized at high flow rates. Wells situated close to rock formations rich in radioactive minerals may be more likely to show anomalies than others.
\end{abstract}

\section{INTRODUCTION}

During 1978 and 1979 the radon $(222 \mathrm{Rn})$ content of nine geothermal wells in Iceland was monitored, and several anomalous changes in radon content preceding local earthquake activity were observed. To be able to apply radon anomalies for earthquake prediction purposes, it is important to establish that a relationship actually exists between radon anomalies and earthquakes and to understand how radon anomalies are related to the earthquake mechanism.

The pioneering work of investigating changes in radon content preceding local earthquakes was carried out by scientists in Tashkent, USSR, about 15 years ago [Antsilevich, 1971; Ulomov and Mavashev, 1971]. They reported seven different radon anomalies that preceded earthquakes of magnitudes between 3.0 and 5.3. More recent studies that have been carried out in Soviet Central Asia are summarized by Asimov et al. [1979]. They present extensive radon data from several networks of radon stations that are situated close to the cities of Tashkent, Andizhan, Dushanbe, and Alma-Ata. At least eleven anomalies that preceded six earthquakes of magnitudes ranging from 5.3 to 7.3 can easily be identified in the data.

\footnotetext{
Copyright (C) 1981 by the American Geophysical Union.
}

Important contributions to the studies of radon as an earthquake precursor have been made by Chinese scientists. Vigorous programs of radon monitoring have been in operation since the early 1970 's in Peking and in provinces such as Hopeh, Liaoning, Szechwan and Yunnan [Liu et al., 1975; Raleigh et al., 1977; Wang, 1978; Suzuki, 1978; Wakita, 1978]. Both long and short term radon anomalies have played a crucial role in the prediction of several major earthquakes such as Haicheng (1975), Lungling (1976), and Sungpan-Pingwu (1976), [Raleigh et al., 1977; Suzuki, 1978; Wakita, 1978]. The Icelandic data presented in this report are in many respects analogous to the long term anomalies observed in China since those are often based on weekly or up to monthly averages [Wakita, 1978].

The program of radon monitoring in Iceland was concentrated in two different areas of transform faulting, the Southern Iceland Seismic Zone (SISZ) and the Tjornes Fracture Zone (TFZ), both of which have been identified as regions of high seismic risk [Bjornsson, 1975, Figure 1]. A number of earthquakes in the magnitude range from 1 to 4.3 were recorded by the local microearthquake network during the two years of radon monitoring. It was found that radon anomalies were rarely observed prior to earthquakes of magnitudes less than two, but for larger earthquakes the probability of observ- 


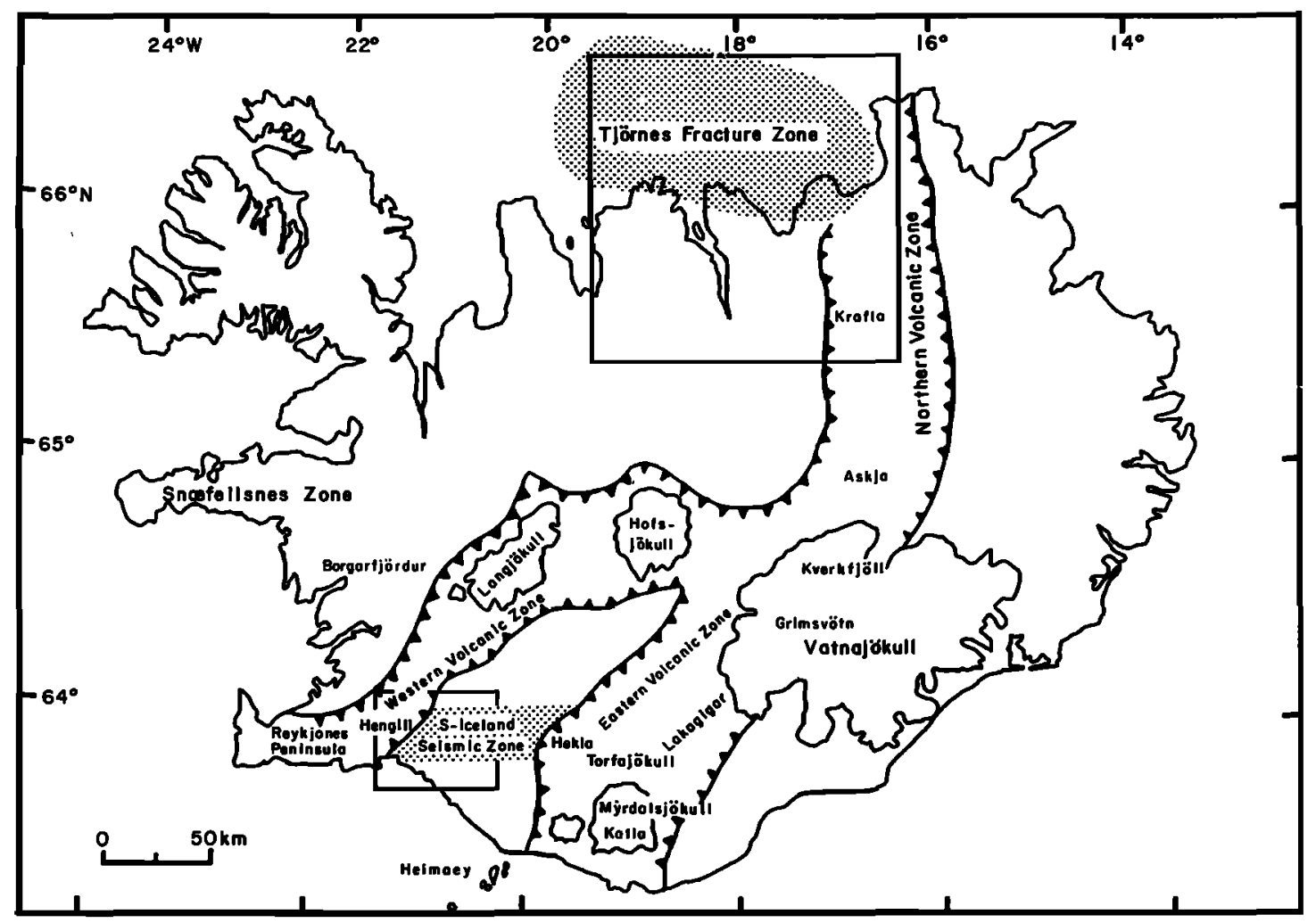

Fig. 1. Map of Iceland showing general tectonic features. The two rectangles delineate Figure 2 and Figure 3. Reproduced from Bjornsson and Einarsson [1974].

ing an anomaly was found to be approximately $65 \%$, based on weekly sampling. The anomalies appeared to occur farther away and to be of longer duration as the earthquake magnitude increased.

The origin and mechanism of the observed radon anomalies and their relationships to earthquakes is poorly understood, although several constraints from laboratory experiments, mathematical modelling and in situ hydraulic experiments have been described [Thorsteinsson, 1975; Andrews, 1977; Dobrovolsky et al., 1979]. It is important to note that all the anomalies were observed at distances of five to ten fault lengths from the respective earthquakes.

To avoid two phase separation problems, suitable sampling methods were developed for the geothermal waters that contained small amounts of a gas phase of nitrogen. Three different sampling methods were applied. The first method that was used during the initial stage of this project gave a sample of the water phase, and essentially neglected the presence of a gas phase. The second method was designed to sample both phases such that the flux of the gas phase could be measured directly. The third method sampled only the gas phase.

In this study the SISZ is emphasized more than the TFZ because of the even geographic distribution of a large number of radon sampling stations and greater seismic hazard.

\section{GEOLOGY AND Flow OF GROUNDWATER}

The Southern Iceland Seismic Zone, SISZ, extends about $70 \mathrm{~km}$ east-west and $10 \mathrm{~km}$ north-south (Figure 1). It is defined by large historic earthquakes of magnitude greater than six that align along an east-west trending zone approximately following the latitude $64^{\circ} \mathrm{N}$ [Bjornsson and Einarsson, 1974].
The $50 \mathrm{~km}$ long region of the SISZ that was monitored for radon content, often called the southern lowlands, is bounded on the west by the Western Volcanic Zone and on the east by the Hreppar anticline, whose axis strikes $N 15^{\circ} \mathrm{E}$ about $10 \mathrm{~km}$ east of the Fludir sampling station (Figure 2). Geothermal wells and hot springs exist throughout the southern lowlands. They result from the high regional geothermal gradient, that ranges from $60^{\circ} \mathrm{C} / \mathrm{km}$ to $150^{\circ} \mathrm{C} / \mathrm{km}$ [Palmason, 1973]. The region east of the anticline has a similar geothermal gradient but no geothermal areas or boreholes are available for radon monitoring.

The geology of the southern lowlands is characterized by Recent rocks close to the volcanic zone and progressively older rocks as the Hreppar anticline is approached [Saemundsson, 1970]. The oldest rocks of age $2.5 \mathrm{~m}$.y. are found in the core of the anticline [Aronson and Saemundsson, 1975]. The basement rocks consist of plateau basalts intercalated with hyaloclastites and tillites, that with increasing age show larger dip towards the volcanic zone. The Recent lavas are horizontal but the oldest ones dip about $10^{\circ}-15^{\circ}$ to the westnorthwest. The root zones of two eroded central volcanic complexes have been mapped in the southern lowlands, one near Geysir and the other, Laxa volcano, near Fludir (see Figure 2). These are characterized by both large basaltic intrusive bodies and acidic and intermediate rocks such as rhyolites and andesites [Saemundsson, 1970].

Abundant evidence of past tectonic deformation such as intrusive dikes, faulting and tilting can be found in the southern lowlands [Saemundsson, 1970]. The basement rocks are frequently cut by tension fractures, strike-slip and large-scale normal faults. The normal faults strike subparallel to the axis 


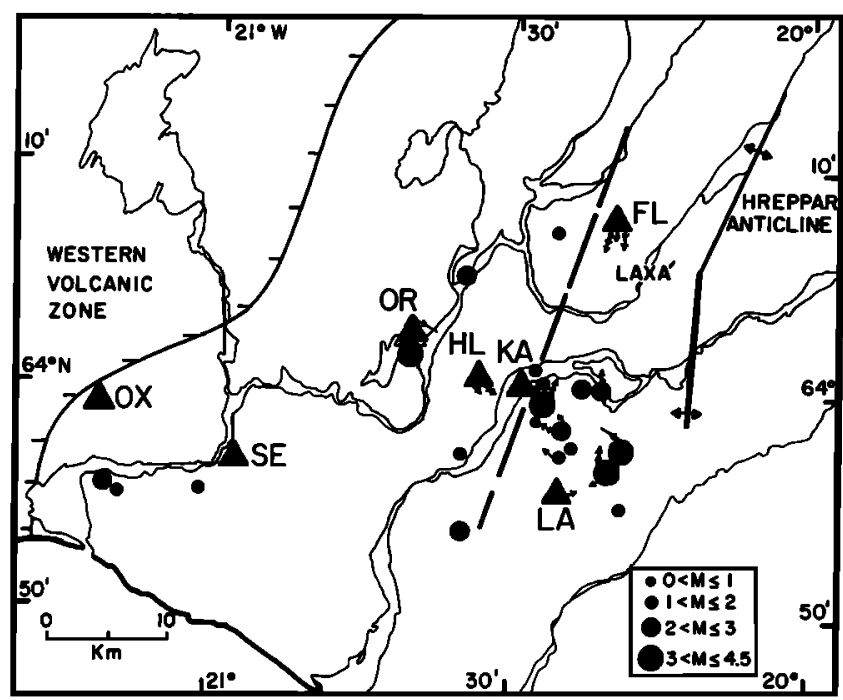

Fig. 2. Radon sampling stations in the Southern Iceland Seismic Zone, shown as triangles; OX-Oxnalaekur, SE-Selfoss, $\mathrm{OR}-\mathrm{Or}$ masstadir, HL-Hlemmiskeid, KA-Kaldarholt, LA-Laugaland, FL-Fludir. Thick dashed line represents the aquiclude; hatched line to the side delineates eastern boundary of Western Volcanic Zone. Filled circles are earthquakes that occurred during 1978 and 1979; see also Table 3 . The quakes with arrows were preceded by radon anomalies at similarly marked stations.

of the volcanic zone. They have an offset of up to several tens of meters and form a step fault pattern with downthrow to the east towards the Hreppar anticline. The strike-slip faults trend approximately either $\mathrm{N} 17^{\circ} \mathrm{E}$ or $\mathrm{N} 55^{\circ} \mathrm{E}$ with an identifiable offset of up to a few meters. The most recent faults are tensional fractures arranged en echelon in northerly trending arrays. Some of these fractures represent the surface manifestations of ruptures in previous large historic earthquakes [Bjornsson, 1975].

Saemundsson [1974] described the structure of the TFZ and its tectonic relation to the evolution of axial rift zones in northern Iceland (Figure 1). The TFZ is a more prominent tectonic feature than the SISZ and extends about $150 \mathrm{~km}$ and strikes $\mathrm{N} 67^{\circ} \mathrm{W}$ with a width of $75 \mathrm{~km}$. Its northern margin is defined by the submarine Grimsey fault that was identified by Einarsson [1976] who used teleseismic data for the period 1955-1974. The southern margin has been recognized on shore as the Husavik fault that was mapped by Saemundsson [1974] as a large oblique-slip fault of right lateral motion. $E i$ narsson [1976] suggested, however, that minor right-lateral motion probably had also occurred on the Dalvik fault which is situated $30 \mathrm{~km}$ south of the Husavik fault. During the last decade the Grimsey fault has been the most seismically active of the three transform faults. Scattered micro-earthquake activity has occurred on the Husavik fault but the Dalvik fault has remained mostly quiescent. The basement rocks consist of lava flows interbedded with sedimentary strata. Near the station Dalvik the flows dip west-southwest but near the station Hafralaekur the dip is to the east. No eroded central volcanic complexes have been mapped in the neighborhood of either Dalvik or Hafralaekur.

The tilted layered structure of the basement rock and the common occurrence of faults indicates that primary and secondary permeabilities exist in the basement rock and are available for flow of groundwater. The primary permeability is along the scoriaceous and often rubbly top and bottom of the basaltic lavas as well as along the whole thickness of the sedimentary or hyaloclastite sequences, which are commonly very porous. Tectonic features such as faults, intrusive dikes or sills produce secondary permeability [Fridleifsson, 1975].

The flow of thermal groundwater is governed by the hydrostatic pressure in the ground and the permeability structure of the rock. Amason [1976], who used deuterium to study the flow of groundwater in Iceland, showed that the hydrostatic pressure of the groundwater can be assumed to follow the mean topography. In the SISZ both types of permeability are subparallel to a groundwater flow direction deduced from an average topographic map of the southern lowlands. This flow direction is in a south-southwest direction from the recharge areas in the interior highlands of the island towards the southern coast [Arnason, 1976]. Amason [1976] indicated that primary permeability was of importance in the TFZ for a flow direction from the interior highlands towards the northern coast.

In summary, the presence of acidic rocks that provide radon rich sources, and the complex but high permeability of local structures indicate that radon anomalies related to local earthquakes could occur in both regions.

\section{RADON SAMPLING Stations}

The network of sampling stations consisted of seven stations in the SISZ (Figure 2) and two in the TFZ (Figure 3). The sampling stations in the SISZ were located within the epicentral zones of large historic earthquakes. In the TFZ only two stations were available for radon monitoring. The waters of all wells contain negligible amounts of recent atmospheric bomb tritium and are independent of variations in stable isotope ratios of recent local meteoric waters [Amason, 1976; $P$. Theodorsson, personal communication, 1977]. In addition, all the stations except for Kaldarholt and Ormsstadir are continuously pumped or artesian. The properties of the radon sam-

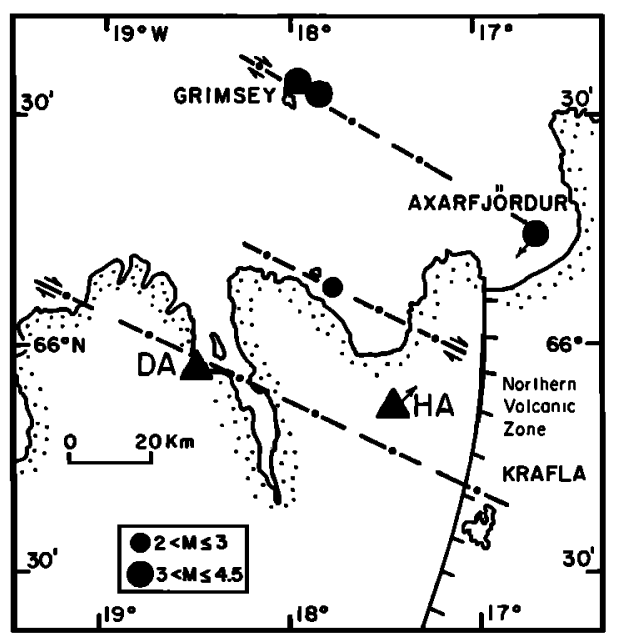

Fig. 3. Radon sampling stations shown as triangles in Northern Iceland along the Tjornes Fracture Zone. Dash-dot lines indicate location of active and inferred strike-slip faults (Grimsey fault to the north, Husavik fault in the middle and Dalvik fault to the south). The pairs of arrows show direction and sense of fault motion obtained from earthquake focal mechanisms [Einarsson, 1976] and geological evidence [Saemundsson, 1974]. Earthquakes from 1978 and 1979 are shown as filled circles (see also Table 3). One quake marked with an arrow was preceded by an anomaly at Hafralaekur. 
TABLE 1. Properties of Radon Sampling Stations

\begin{tabular}{|c|c|c|c|c|c|c|c|c|}
\hline \multirow{2}{*}{$\begin{array}{l}\text { Sampling } \\
\text { Station }\end{array}$} & \multirow{2}{*}{$\begin{array}{l}\text { Code } \\
\text { Name }\end{array}$} & \multirow{2}{*}{$\begin{array}{l}\text { Tempera- } \\
\text { ture, } \\
{ }^{\circ} \mathbf{C}\end{array}$} & \multirow{2}{*}{$\begin{array}{c}\text { Depth, } \\
\text { m }\end{array}$} & \multirow{2}{*}{$\begin{array}{c}{ }_{\mathrm{dpm}}^{222} \mathrm{Rn}, \\
\mathrm{kg} \mathrm{H} \mathrm{H}_{2} \mathrm{O}\end{array}$} & \multirow{2}{*}{$\begin{array}{l}\mathrm{Cl}^{-}, \\
\text {ppm }\end{array}$} & \multicolumn{2}{|c|}{ Location } & \multirow[b]{2}{*}{ Remarks } \\
\hline & & & & & & Latitude & Longitude & \\
\hline $\begin{array}{l}\text { Dalvik, W10 } \\
\text { Fludir, W5 } \\
\text { Hafralaekur } \\
\text { Hlemmiskeid }\end{array}$ & $\begin{array}{l}\text { DA } \\
\text { FL } \\
\text { HA } \\
\text { HL }\end{array}$ & $\begin{array}{l}65 \\
94 \\
74 \\
66\end{array}$ & $\begin{array}{r}838 \\
321 \\
100 \\
85\end{array}$ & $\begin{array}{r}80 \\
520 \\
90 \\
425\end{array}$ & $\begin{array}{c}9.0 \\
24 \\
9.5 \\
170\end{array}$ & $\begin{array}{l}65 N 56.6 \\
64 N 07.7 \\
65 N 52.5 \\
64 N 00.6\end{array}$ & $\begin{array}{l}18 W 31.7 \\
20 W 19.5 \\
17 W 27.1 \\
20 W 33.2\end{array}$ & $\begin{array}{l}\text { Deep water pump } \\
\text { Artesian } \\
\text { Artesian, open well } \\
\text { Pumps at head, open } \\
\text { well }\end{array}$ \\
\hline Kaldarholt & $\mathbf{K A}$ & 62 & 38 & 570 & 230 & $64 N 00.2$ & $20 W 28.8$ & $\begin{array}{l}\text { Pump at head, open } \\
\text { well }\end{array}$ \\
\hline $\begin{array}{l}\text { Laugaland, W2 } \\
\text { Ormsstadir }\end{array}$ & $\begin{array}{l}\text { LA } \\
\text { OR }\end{array}$ & $\begin{array}{l}48 \\
50\end{array}$ & $\begin{array}{l}200 \\
280\end{array}$ & $\begin{array}{l}475 \\
450\end{array}$ & $\begin{array}{r}38 \\
155\end{array}$ & $\begin{array}{l}63 \mathrm{~N} 55.0 \\
64 \mathrm{~N} 02.5\end{array}$ & $\begin{array}{l}20 W 25.0 \\
20 W 40.0\end{array}$ & $\begin{array}{l}\text { Pump at head, artesian } \\
\text { Pump at head, open } \\
\text { well }\end{array}$ \\
\hline $\begin{array}{l}\text { Selfoss, W9 } \\
\text { Oxnalaekur }\end{array}$ & $\begin{array}{l}\text { SE } \\
\text { OX }\end{array}$ & $\begin{array}{r}74 \\
100\end{array}$ & $\begin{array}{r}1334 \\
953\end{array}$ & $\begin{array}{l}120 \\
135\end{array}$ & $\begin{array}{l}245 \\
\text { NA }\end{array}$ & $\begin{array}{l}63 N 56.8 \\
63 N 59.1\end{array}$ & $\begin{array}{l}20 W 57.5 \\
21 W 11.3\end{array}$ & $\begin{array}{l}\text { Deep water pump } \\
\text { Artesian, high } \\
\text { temperature well }\end{array}$ \\
\hline
\end{tabular}

pling stations are summarized in Table 1. The hot water drawn from these wells is exploited for space heating of local villages or farms. At each station a local volunteer collected weekly samples (Fludir was sampled twice weekly) which were shipped to Reykjavik for analysis. The lag time from the collection of a sample until the analysis was done was about seven days, and the final datum point was plotted on a graph within the next week. All radon values were corrected for decay during the time interval between sampling and analysis and the reported values represent the radon concentration at the time of sampling.

The dense spacing of stations in the SISZ (10-15 km) permitted studies of radon anomalies as a function of earthquake magnitude and distance between the station and epicenter. The effect of different well properties and regional factors such as geology and hydrology at each station could also be examined when evaluating the radon data. The two TFZ stations were too widely spaced for a similar study.

The easternmost sampling station in the SISZ, Fludir is located $10 \mathrm{~km}$ west of the Hreppar anticline. Samples were collected from well 5 . (Well numbers refer to a code established by the National Energy Authority of Iceland.) Saemundsson [1970] argued that 500-600 m thickness of the original lavapile in this region has been eroded away. Therefore, the well penetrates much deeper stratigraphically and samples water from more compacted formations than do other wells in the SISZ. Also, acidic intrusives and extrusives that could be rich in radioactive elements are found at Laxa volcano, within a few kilometers of Fludir. Unfortunately, no analysis of the radioactive mineral content of samples from these rock formations is available. Wood et al. [1979] demonstrated, however, that volcanic rock erupted at central volcanic complexes in Iceland in general reflected up to ten times higher abundances of radiogenic isotopes than the basalts erupted from shield volcanoes in Iceland.

The data shown in Table 2 indicate that the well water at Fludir is high in $\mathrm{CH}_{4}$ and $\mathrm{He}$ relative to the other stations. The wellhead temperature at Fludir is higher than at other stations and the water is also observed to be high in dissolved $\mathrm{CO}_{2}$ and $\mathrm{H}_{2} \mathrm{~S}$ [Amorsson, 1970]. The helium isotope ratios in Table 2 indicate dominance of the mantle component over both crustal and atmospheric components at Fludir, Hlemmiskeid, and Selfoss. At Fludir, however, the helium isotope ratio is approximately $6 \%$ lower than at other stations. This is interpreted to be caused by mixing of a mantle component with either a crustal or an atmospheric source of helium. One possible source of a crustal helium could be the acidic intrusives that are presumed to be relatively abundant in radioactive minerals.

The sampling station Laugaland, well 2, is situated $25 \mathrm{~km}$ south of Fludir along the approximate direction of groundwater flow. Fludir and Laugaland appear to be on the eastern side of an aquiclude that strikes north-northeast and divides the southern lowlands into two chemically distinct zones of upflow [Arnorsson, 1970; Stefansson, 1975] (Figure 2). As a result of applying chloride and boron for geothermal prospecting, Arnorsson [1970] proposed that the southern lowlands could be divided on the basis of $\mathrm{Cl}^{-} / \mathrm{B}$ ratios into several distinct zones of upflow separated by aquicludes. When combining Arnorsson's data with radon data from the same wells and hot springs, it was found that high ratios of $\mathrm{Rn} / \mathrm{Ca}^{++}$and $\mathrm{F}^{-} / \mathrm{Cl}^{-}$occurred only east of the aquiclude shown in Figure 2. High ratios of $\mathrm{Rn} / \mathrm{Ca}^{++}$and $\mathrm{F}^{-} / \mathrm{Cl}^{-}$are characteristic of thermal waters that flow through acidic rocks. Wells and hot springs west of the aquiclude reflected uniformly low ratios of $\mathrm{Rn} / \mathrm{Ca}^{++}$and $\mathrm{F}^{-} / \mathrm{Cl}^{-}$.

TABLE 2. Helium Isotope and Gas Data on Sampling Stations in the SISZ: January 15, 1979

\begin{tabular}{|c|c|c|c|c|c|c|c|c|}
\hline $\begin{array}{l}\text { Sampling } \\
\text { Station }\end{array}$ & $\begin{array}{l}\text { Well } \\
T,{ }^{\circ} \mathrm{C}\end{array}$ & $\begin{array}{c}\text { Sampling } \\
T,{ }^{\circ} \mathrm{C}\end{array}$ & $\begin{array}{c}{ }^{222} \mathrm{Rn}, \\
\mathrm{dpm} / \mathrm{kg} \mathrm{H}_{2} \mathrm{O}\end{array}$ & $\begin{array}{l}\mathrm{N}_{2} / \mathrm{Ar}^{*} \\
\text { (by vol) }\end{array}$ & $\begin{array}{c}\text { Ar, } \\
\mathrm{cm}^{3} / \mathrm{kg}\end{array}$ & $\begin{array}{c}\mathrm{CH}_{4}, \mathrm{~cm}^{3} \\
(\mathrm{stp}) / \mathrm{kg}\end{array}$ & $\begin{array}{c}\mathrm{He}, " \mu \mathrm{cm}^{3} \\
\text { (stp)/g }\end{array}$ & $R / R+$ Air \\
\hline $\begin{array}{l}\text { Hlemmiskeid } \\
\text { Selfoss W9 } \\
\text { Fludir W5 } \\
\text { Fludir W5 }\end{array}$ & $\begin{array}{l}66 \\
74 \\
94 \\
94\end{array}$ & $\begin{array}{l}66 \\
62 \\
30 \\
27\end{array}$ & $\begin{array}{r}315 \\
89 \\
533 \\
533\end{array}$ & $\begin{array}{l}41.1 \\
42.6 \\
\text { NA } \\
46.5\end{array}$ & $\begin{array}{c}0.350 \\
0.361 \\
\text { NA } \\
0.460\end{array}$ & $\begin{array}{c}0.054 \\
0.042 \\
\text { NA } \\
0.152\end{array}$ & $\begin{array}{l}1.04 \\
1.38 \\
1.72 \\
1.74\end{array}$ & $\begin{array}{l}18.9 \\
18.3 \\
17.4 \\
17.6\end{array}$ \\
\hline
\end{tabular}

Radon values were obtained from separate samples. NA, not applicable.

"Samples analyzed at the Helium Isotope Laboratory at the Scripps Institution of Oceanography.

$\dagger R={ }^{3} \mathrm{He} /{ }^{4} \mathrm{He}$. 
The sampling stations, Kaldarholt, Hemmiskeid, and Ormsstadir that are located along a west-northwest striking line midway between Fludir and Laugaland, together with the sampling station Selfoss probably fall along a rather broad flow line on the western side of the aquiclude. The $38 \mathrm{~m}$ deep well at Kaldarholt may show radon values that depend upon usage, since the water is pumped into a small pressurized tank prior to sampling. The well at Hlemmiskeid was pumped continuously at a steady flow rate. At Ormsstadir the owner had installed a gas-separator at $5 \mathrm{~m}$ depth below the water level in the well. The separator allows a small part of the gas phase of nitrogen to escape up through the open wellhead.

The geothermal field at Selfoss situated $15 \mathrm{~km}$ east of the Western Volcanic Zone, has been exploited since 1944 by the local town. Currently three deep wells (numbers 8, 9, and 10) can withdraw fluid from the field at a rate of $135 \mathrm{l} / \mathrm{s}$ and a temperature of $78^{\circ} \mathrm{C}$. The wells form a triangle, in which the distance from well 8 to wells 10 and 9 is about $200 \mathrm{~m}$ and the distance between wells 9 and 10 is $315 \mathrm{~m}$. During the first half of 1978, samples were collected from well 8. In June 1978 the pumping from that well was stopped due to maintenance operations that lasted for three months. Since well 9 was to remain in continuous operation for the next few years, the sampling was permanently transferred to that well. Well 9 takes water from a $54^{\circ} \mathrm{C}$ hot aquifer at $300 \mathrm{~m}$ depth and a $88^{\circ} \mathrm{C}$ hot aquifer below $600 \mathrm{~m}$ depth [Halldorsson, 1980].

The well at sampling station Oxnalaekur penetrates nontilted recent lava flows on the boundary between the Western Volcanic Zone and the SISZ. The large high-temperature ( $T$ $>150^{\circ} \mathrm{C}$ ) area, Hengill is located along a flowline upstream from Oxnalaekur, about 5 to $10 \mathrm{~km}$ distance. During 1979 the well was not sampled because of logistical difficulties.

Two sampling stations, Dalvik and Hafralaekur, were sampled for radon in the TFZ. At Dalvik samples were collected from well 10. This well was drilled in the fall of 1977 and cuts one large aquifer right at the bottom of the well. The aquifer is associated with an intrusive basalt dike. The Dalvik fault strikes west-northwest about $5 \mathrm{~km}$ north of the well. The well at Hafralaekur is artesian, $100 \mathrm{~m}$ deep and the water has a temperature of $74^{\circ} \mathrm{C}$. The Hafralaekur station is situated between the Dalvik and the Husavik faults and about 30 to 40 $\mathrm{km}$ away from the presently ongoing tectonic events at Krafia in the Northern Volcanic Zone [Bjornsson et al., 1979].

\section{Methods of SAMPLING AND RAdON MEASUREMENT}

A major part of this work consisted of developing sampling methods suitable for the geothermal waters that contained small amounts of a nitrogen gas phase. The analytical technique used to measure radon content in water or gas samples had already been developed at Lamont-Doherty for analysis of seawater [Broecker, 1965].

The geothermal waters being sampled are of meteoric origin [Amason, 1976]. Before percolating into the ground, these waters equilibrated with air $\left(\mathrm{N}_{2}, \mathrm{O}_{2}\right.$, etc.) at approximately 1 atm and $4^{\circ} \mathrm{C}$. From Weast [1977-1978], it can be shown that about $18 \mathrm{~cm}^{3}$ of $\mathrm{N}_{2}$ dissolves per liter of water at $1 \mathrm{~atm}$ and $4^{\circ} \mathrm{C}$. During passage through the upper crust the water changes its gas content. Oxygen is lost through chemical reactions with the rock matrix and some trace amounts of other gases, such as radon, are acquired.

When the geothermal water rises up through a well, for example at a temperature of $70^{\circ} \mathrm{C}$, it starts releasing some of its $\mathrm{N}_{2}$ as bubbles at a depth of $20-30 \mathrm{~m}$. At the wellhead the wa- ter has released about $10 \mathrm{~cm}^{3}$ of $\mathrm{N}_{2}$ per liter of water at 1 atm as bubbles. This flux ratio of gas to water $(\sim 1 / 100)$ can be measured easily and used as an indicator to show whether some of the gas phase has been lost or whether a heterogeneous increase in bubble formation is occurring. Sampling conditions vary from one station to another because the plumbing differs at the various wellheads. At stations where the wellhead is open (see Table 1), some of the gas phase can be lost prior to sampling. At some stations an increase in bubble formation may have resulted from turbulence in the water which was created by the pumping.

During the summer of 1978 samples of the gas phase from the radon stations Fludir, Hlemmiskeid, Laugaland, and Selfoss, Hafralaekur and Oxnalaekur were analyzed for the following gases: $\mathrm{O}_{2},\left(\mathrm{CO}_{2}+\mathrm{H}_{2} \mathrm{~S}\right), \mathrm{CH}_{4}, \mathrm{H}_{2}$ and $\left(\mathrm{N}_{2}+\right.$ inert gases). The results of these analyses indicated that only $\left(\mathrm{N}_{2}+\right.$ inert gases) were present at all the stations except at Oxnalaekur, where $4 \%$ (volume) of $\left(\mathrm{CO}_{2}+\mathrm{H}_{2} \mathrm{~S}\right)$ was found. In addition, four water samples were collected for general gas and helium isotope analysis. These data are shown in Table 2. The $\mathrm{N}_{2}$ /Ar ratio indicates that all sampled stations are supersaturated in $\mathrm{N}_{2}$. The $\mathrm{N}_{2}$ supersaturation can be accomplished, for example, through mixing of air-saturated cold groundwater with a previously degassed component of geothermal water. The Ar concentrations for Hemmiskeid and Selfoss correspond to an original equilibrium temperature between air and water of approximately $20^{\circ} \mathrm{C}$. This indicates that about $25 \%$ of the initial gas phase is lost, if the assumption is made that originally the water being sampled equilibrated with air at $4^{\circ} \mathrm{C}$ and $1 \mathrm{~atm}$. The gas loss occurs presumably during ascent of the water to the wellhead. The Ar concentration of Fludir indicates no significant gas loss.

The empirical distribution coefficient of radon between equal volumes of air and water is drawn as a solid line in Figure 4 [D'Amore, 1976]. Radon in the gas phase and in the degassed water phase was measured. Samples that were collected at the wellhead temperature were found to be in equilibrium (see Figure 4). Samples from Fludir and Oxnalaekur, did not show equilibrium because a slight sampling effect was introduced by drawing the samples through a cooling spiral. Presumably samples from both Fludir and Oxnalaekur would show equilibrium at the wellhead temperature. Although per unit volume the gas phase is five to ten times richer in radon than the water phase (Figure 4), the large flux ratio of water to gas $(100 / 1)$ demonstrated that usually about 90\% of the total radon flux is carried by the water phase and only $10 \%$ by the gas phase.

In January 1978 local people were asked to collect weekly a water sample, shown as solid dots in Figures 6 through 10. The bottle was prefilled with helium, and during sampling it was filled from the base, making the water push out the helium blanket until the bottle was 3/4 full. Immediately after filling, the clamps on the hoses of the bottle were closed. This method was abandoned because fluctuations in the volume of gas bubbles retained in the remaining He-space seemed to be responsible for some of the scatter in the data.

A more precise way of sampling this type of two-phase system is to draw a total sample, shown as open circles in Figures 6 through 10. During sampling an evacuated bottle was connected to the wellhead and a vacuum gauge. The bottle was then filled until the gauge showed 1 atm pressure (see Figure 5). Before disconnecting the bottle from the sampling board, the clamps on the hoses of the bottle were closed. This sam- 


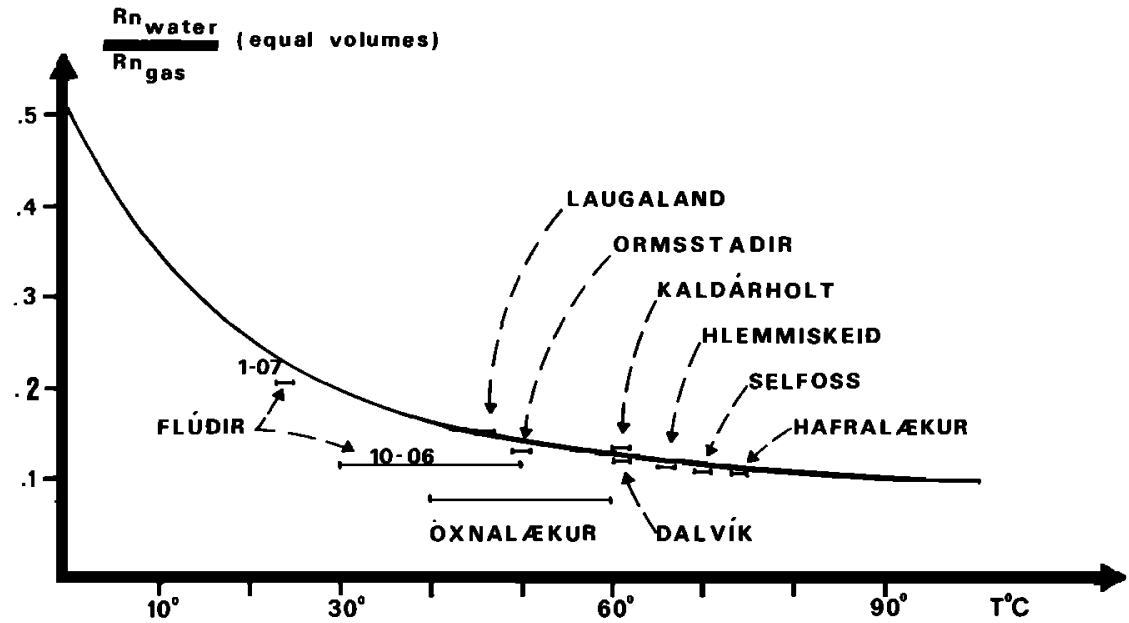

Fig. 4. Distribution coefficient of radon between equal volumes of water and air as a function of temperature.

pling took about one minute. The method has the advantage that it automatically monitors the flux ratio of gas to water. This made it possible to tell if an observed increase in radon content was caused by a real increase in the water of the aquifer or was induced by gross changes in the flux ratio of gas to water. In rare cases total samples have been corrected for an excessive volume of gas; these are plotted as solid triangles in Figures 9 and 10. Total samples have been collected at all of the sampling stations since late May 1978.

At four sampling stations we also chose to collect gas samples, since the gas phase has five to ten times higher radon activity than the water phase (Figure 4). The gas sample should give a better average radon value because it took about one hour to draw half a liter of gas at a sampling flowrate of $1 / 2$ liter per minute. First the sampling bottle was filled with well water and then inverted, allowing gas to expel water from the

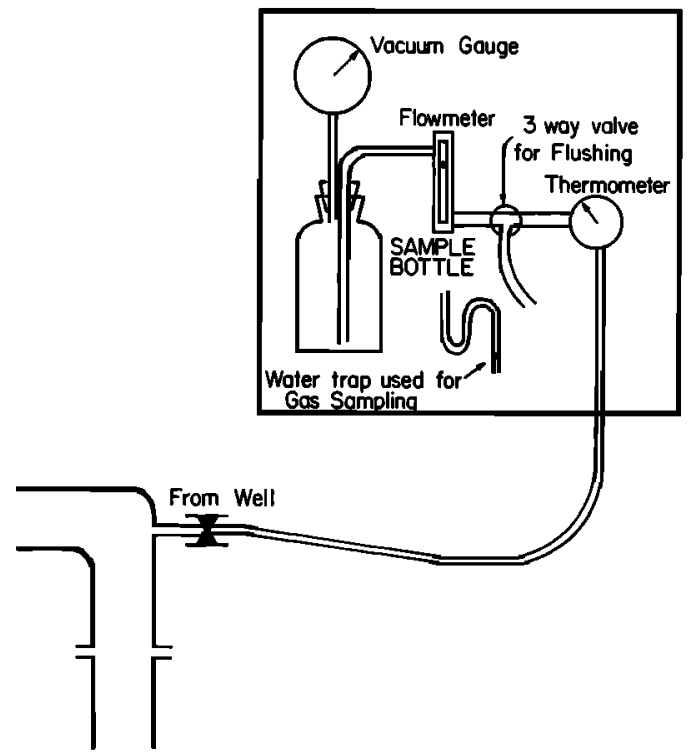

Fig. 5. Apparatus used to sample low temperature wells. The bottle shown is drawing a total sample. When a gas sample is drawn, the hose shown connected to the vacuum gauge is fastened to the water trap. First the bottle is filled with well water and then inverted, to allow the gas phase to expel the water phase. sample bottle. To convert the value of radon per liter of gas ( $\mathrm{Rn} / 1$ gas) into an equivalent total sample $\left(\mathrm{Rn} / \mathrm{kg} \mathrm{H}_{2} \mathrm{O}\right)$, we use the formula

$$
\mathbf{R n} / \mathbf{k g}_{\mathrm{H}_{2} \mathrm{O}}=\left[\alpha(T)+\frac{1 \text { gas }}{\mathbf{k g ~ H} \mathrm{O}}\right] \frac{\mathrm{Rn}}{1 \text { gas }}
$$

The ratio ( 1 gas $/ \mathrm{kg} \mathrm{H}_{2} \mathrm{O}$ ) was determined using a known sampling time and a flowmeter. The distribution coefficient $\alpha(T)$ was read from the empirically determined curve in Figure 4, where $T$ is the sampling temperature.

Usually the total sample and the gas sample should give the same radon concentration normalized to a kilogram of water. In the case of smaller earthquakes, however, the expected radon signal that sustains the radon anomaly may originate from a small source and be strongly perturbed by local conditions, and the radon in the water phase need not be in equilibrium with the radon in the gas phase. Thus an instantaneous sample like the total sample and an average sample like the gas samples can show different results.

In the laboratory the radon was stripped from the water and/or gas sample, using helium as a carrier gas, and adsorbed onto activated charcoal at $-60^{\circ} \mathrm{C}$. The charcoal column was evacuated at both $-60^{\circ} \mathrm{C}$ and room temperature to remove impurities and then heated to $470^{\circ} \mathrm{C}$. Helium was then used to sweep the liberated radon into an evacuated counting cell (lucas cell) and the cell was placed against a photomultiplier tube in a light-tight chamber for counting. All efficiencies were routinely determined by extracting radon from a standard solution of parent radium 226. Circulation blanks were periodically run on the extraction-transfer system to check against radium 226 contamination. The analytical accuracy of the method was about $3 \%$.

\section{Local SeISMICITY}

The seismicity of Iceland has been described by Tryggvason [1973], Bjornsson and Einarsson [1974], and Einarsson [1979]. The historical seismicity and tectonics of both the SISZ and TFZ have been treated in detail by Bjornsson [1975] and Einarsson [1976], respectively. In this report, the main emphasis is put on the local microearthquake activity that occurred in the SISZ and TFZ during 1978 and 1979.

The SISZ experienced unusually high seismic activity in 
1978 followed by a period of seismic quiescence in 1979 . The more noticeable features of the 1978 seismicity consisted of an earthquake swarm in July and a foreshock-mainshock-aftershock sequence in November. The swarm on July 3 occurred $6 \mathrm{~km}$ east of Kaldarholt and contained several shocks of magnitude 2.6 with the largest one of magnitude 2.7. The sequence on November 18 and 19 started out at a similar location as the July swarm but migrated $5 \mathrm{~km}$ westward to the sampling station, Kaldarholt, where the main shock of magnitude 4.3 was located. In addition several single shocks occurred scattered throughout the zone. During 1979 most of the earthquakes had magnitudes less than 2 except for one whose magnitude was 2.8 .

The TFZ showed less activity during 1978 than during 1979; 1978 was characterized by seismic quiescence and 1979 by unusually high seismic activity that mostly occurred more than $\mathbf{4 0} \mathrm{km}$ away from the sampling stations Dalvik and Hafralaekur. In May 1978 two earthquakes of magnitude 3.0 and 3.1 occurred $40 \mathrm{~km}$ north of Hafralaekur on the Husavik fault. Numerous earthquake sequences, mostly of swarm type that took place during 1979, were located close to the island of Grimsey and in Axarfjordur towards the east (Figure 3). The largest event in the neighborhood of Grimsey occurred in April and was of magnitude 4.4. The activity in the Axarfjordur region culminated with a 4.1 event in December.

There exist no general rules about how to select earthquakes that possibly can correlate with radon data from one or more stations. Based on limited experimental evidence, it was decided to apply the following rules:

1. Only earthquakes in the respective seismic zones are included. For example, all earthquakes in adjacent volcanic zones are omitted. This rule resulted from the following observations. First, none of the seismicity $(M \leq 4)$ associated with rifting events in the Northern Volcanic Zone [Bjornsson et al., 1979] appeared to induce changes in the radon content at Hafralaekur. Second, at Oxnalaekur and Selfoss no obvious relationship could be found between radon data and earthquakes $(M \leq 3.5)$ in the Western Volcanic Zone.

2. The empirical magnitude-distance relationship

$$
M=2.4 \log _{10} D-0.43
$$

was applied such that an earthquake of magnitude $\boldsymbol{M}$ could be preceded by a radon anomaly at a distance of less than or equal to $D(\mathrm{~km})$. Thus it will often be stated whether an earthquake is within the distance range of a radon station or not.

This relationship was determined by using the following method. First, the epicentral distance was plotted as a function of magnitude for radon anomalies that have been reported to be associated with the following earthquakes: Gasli (1976), USSR [Asimov et al., 1979]; Szechwan Luhuo (1973), Szechwan Mapien (1973), China [Wakita, 1978]; Izu-Oshima (1978), Japan [Wakita et al., 1980]. The three anomalies observed at Fludir were also included in the plot. Second, a straight line was drawn into the plot, approximately parallel to the trend of the data such that all the data points were located at the shortest distance on one side of the line. This line constitutes the empirical magnitude-distance relationship presented above. This relationship, that takes into account reports from the USSR and China of very long epicentral distances, is intended to scale those distances down to smaller earthquake magnitudes.

3. In the case that several earthquakes occurred clustered in time and space, the largest one was picked as being preceded by the radon anomaly. If several earthquakes of similar magnitude occurred within a few days, the first one was selected and the others were said to be overprinted.

These rules are designed to minimize the number of false alarms and maximize the number of successfully observed anomalies. Of course, an important part of this work is to modify the rules as more data become available.

Table 3 contains parameters of the earthquakes that were selected according to the above rules, and thus are of interest for analysis with the radon data. Table 3 is not intended as an exhaustive catalogue of the seismicity during 1978 and 1979 in the SISZ and TFZ. The epicentral locations and magnitude calculations were done at the Science Institute, University of Iceland, using data from a short-period seismic network of four to eight local stations. The epicentral locations are of high quality but the seismic network coverage was not sufficient to rigorously constrain the depth of the events. The earthquakes that are listed in Table 3 are plotted in Figures 2 and 3.

\section{RADON DATA}

Total samples were collected at all stations and thus constitute the largest and most significant part of the data presented in this report. In some cases the flux ratio of gas to water, the wellhead temperature, pressure or flow rate were measured at the time of sampling. Since August 1979 chloride concentration has been determined in each sample after the radon analysis. These additional variables remained essentially constant at most stations and, with the exception of Selfoss, are not plotted. The variations of the radon data with time contained long-term seasonal trends, short-term fluctuations and possible earthquake-related changes. When comparing data from 1978 and 1979 obtained at the same station in the SISZ, it is clear that the 1979 data in most cases are more stable. This could be related to higher seismic activity in 1978 or less probably, to training of personnel and more efficient implementation of sampling procedures.

Radon anomalies were identified in the time series shown in Figures 6 through 10 by applying the following method. For each data set of a total sample or a gas sample that covered a time period of one year, a mean value of radon content and a corresponding standard deviation were calculated. If one or more measured radon values deviated from the yearly mean by more than twice the standard deviation, an event was assumed to have occurred in the respective time series. The event was called a radon anomaly if it preceded an earthquake that satisfied rule 2 above. The event was identified as a false alarm if it was not followed by an earthquake. The onset time of a radon anomaly was defined as the time midway between the last point in the long-term trend of the time series and the first point that outlined the event. The time duration of a radon anomaly was defined as the time interval from the onset time to the time of the earthquake. In Figure 11 three radon anomalies from Fludir are shown to demonstrate the method used to determine the duration of radon anomalies.

The radon data collected twice a week at Fludir are shown in Figure 6. During 1978 the total sample data displayed three distinct events that preceded local earthquakes. Two of them that occurred in August and November coincided with unclear events in the gas sample data but the gas data showed a higher mean value and large fluctuations during 1978 than the 
TABLE 3. Parameters of Earthquakes and Related Radon Anomalies

\begin{tabular}{|c|c|c|c|c|c|c|c|c|c|c|c|c|}
\hline \multirow{3}{*}{$\begin{array}{l}\text { Earthquake } \\
\text { Number }\end{array}$} & \multirow[b]{3}{*}{ Date } & & & \multirow{3}{*}{$\begin{array}{l}\text { Depth, } \\
\text { km }\end{array}$} & \multirow{3}{*}{$\begin{array}{c}\text { Magnitude, } \\
M_{L}\end{array}$} & \multirow{3}{*}{$\begin{array}{c}\text { Horizontal } \\
\text { Location } \\
\text { Error, } \\
\text { km }\end{array}$} & \multicolumn{3}{|c|}{ Radon Anomaly } & \multicolumn{3}{|c|}{ Radon Anomaly } \\
\hline & & \multicolumn{2}{|c|}{ Location } & & & & \multirow{2}{*}{$\begin{array}{c}\text { Station } \\
\text { Code } \\
\text { Name }\end{array}$} & \multirow{2}{*}{$\begin{array}{c}\text { Distance, } \\
\mathbf{k m}\end{array}$} & \multirow{2}{*}{$\begin{array}{c}\text { Duration, } \\
\text { days }\end{array}$} & \multirow{2}{*}{$\begin{array}{c}\text { Station } \\
\text { Code } \\
\text { Name }\end{array}$} & \multirow{2}{*}{$\begin{array}{c}\text { Distance, } \\
\mathbf{k m}\end{array}$} & \multirow{2}{*}{$\begin{array}{c}\text { Duration, } \\
\text { days }\end{array}$} \\
\hline & & Latitude & Longitude & & & & & & & & & \\
\hline $\begin{array}{l}1 \\
2\end{array}$ & $\begin{array}{l}\text { March 31, } 1978 \\
\text { May 30, } 1978\end{array}$ & $\begin{array}{l}\text { 64N02.2 } \\
\text { 63N53.8 }\end{array}$ & $\begin{array}{l}20 W 40.2 \\
20 W 34.7\end{array}$ & $\begin{array}{c}17 \\
7.2\end{array}$ & $\begin{array}{l}3.3 \\
2.3\end{array}$ & $\begin{array}{l}2.9 \\
2.0\end{array}$ & & & & & & \\
\hline 3 & July 3,1978 & $64 N 00.2$ & $20 W 20.8$ & 0 & 2.7 & 0.6 & $\mathbf{F L}$ & 14 & $22 \pm 1$ & & & \\
\hline$(4)^{1}$ & July 9,1978 & 64N05.1 & 20W05.1 & $20 W 34.9$ & 5.4 & 2.6 & 1.6 & & & & & \\
\hline 5 & Aug. 28,1978 & 63N56.7 & $20 \mathrm{~W} 19.5$ & 8.6 & 3.4 & 1.8 & $\mathbf{L A}$ & 5 & $17 \pm 4$ & FL & 21 & $17 \pm 4$ \\
\hline 6 & Sept. 3, 1978 & 63N55.5 & $21 W 10.1$ & 7.2 & 2.6 & 1.5 & & & & & & \\
\hline 7 & Oct. 30,1978 & 63N57.5 & $20 \mathrm{~W} 18.7$ & 5.5 & 3.8 & 1.0 & OR & 20 & $24 \pm 3$ & & & \\
\hline 8 & Nov. 16,1978 & $64 N 00.3$ & $20 \mathrm{~W} 27.7$ & 3.8 & 1.9 & 1.2 & & & & & & \\
\hline$(9)^{1}$ & Nov. 18,1978 & $64 \mathrm{~N} 00.0$ & $20 \mathrm{~W} 21.9$ & 4.4 & 3.2 & 1.2 & & & & & & \\
\hline 10 & Nov. 19,1978 & $63 \mathrm{~N} 59.7$ & $20 \mathrm{~W} 27.8$ & 5.0 & 4.3 & 1.3 & $\mathbf{F L}$ & 16 & $18 \pm 1^{4,5}$ & & & \\
\hline 11 & April 18, 1979 & 63N58.8 & $20 \mathrm{~W} 27.5$ & 8.0 & 1.0 & 0.7 & & & & & & \\
\hline 12 & June 12, 1979 & $63 N 54.8$ & $20 W 18.9$ & 6.4 & 1.5 & 0.9 & & & & & & \\
\hline 13 & June 18, 1979 & 64N07.2 & $20 W 25.6$ & 7.5 & 1.8 & 0.9 & & & & & & \\
\hline 14 & June 29, 1979 & 63N57.2 & $20 \mathrm{~W} 24.9$ & 2 & 1.9 & 0.5 & HL & 9 & $19 \pm 4$ & & & \\
\hline 15 & July 25, 1979 & 63N57.2 & $20 W 34.8$ & 6.2 & 1.8 & 0.5 & & & & & & \\
\hline 16 & Aug. 9, 1979 & 63N55.3 & $21 \mathrm{~W} 01.2$ & 7.0 & 1.8 & 1.7 & & & & & & \\
\hline 17 & Sept. 5, 1979 & 63N58.3 & $20 \mathrm{~W} 24.7$ & 9.1 & 2.8 & 0.5 & HL & 8 & $17 \pm 2^{2}$ & $\mathbf{K A}$ & 5 & $33 \pm 4$ \\
\hline 18 & Nov. 5, 1979 & $63 \mathrm{~N} 57.6$ & $20 W 24.0$ & 8.3 & 1.8 & 1.3 & & & & & & \\
\hline 19 & Nov. 13,1979 & $64 \mathrm{~N} 01.0$ & $20 \mathrm{~W} 27.6$ & 7.4 & 1.6 & 1.1 & & & & & & \\
\hline 20 & Dec. 29, 1979 & 63N55.1 & 21W09.5 & 1.1 & 2.0 & 1.4 & & & & & & \\
\hline 21 & Feb. 7, 1979 & $66 \mathrm{~N} 31^{3}$ & $18 \mathrm{~W} 00^{3}$ & $5^{3}$ & 3.9 & $10^{3}$ & & & & & & \\
\hline 22 & April 30, 1979 & $66 \mathrm{~N} 32.6$ & 17 W51.5 & 9.7 & 4.4 & 2.3 & & & & & & \\
\hline 23 & Dec. 15,1979 & $66 \mathrm{~N} 14.4$ & $16 W 41.5$ & 4.4 & 4.1 & 1.0 & HA & 60 & $37 \pm 9^{5}$ & & & \\
\hline
\end{tabular}




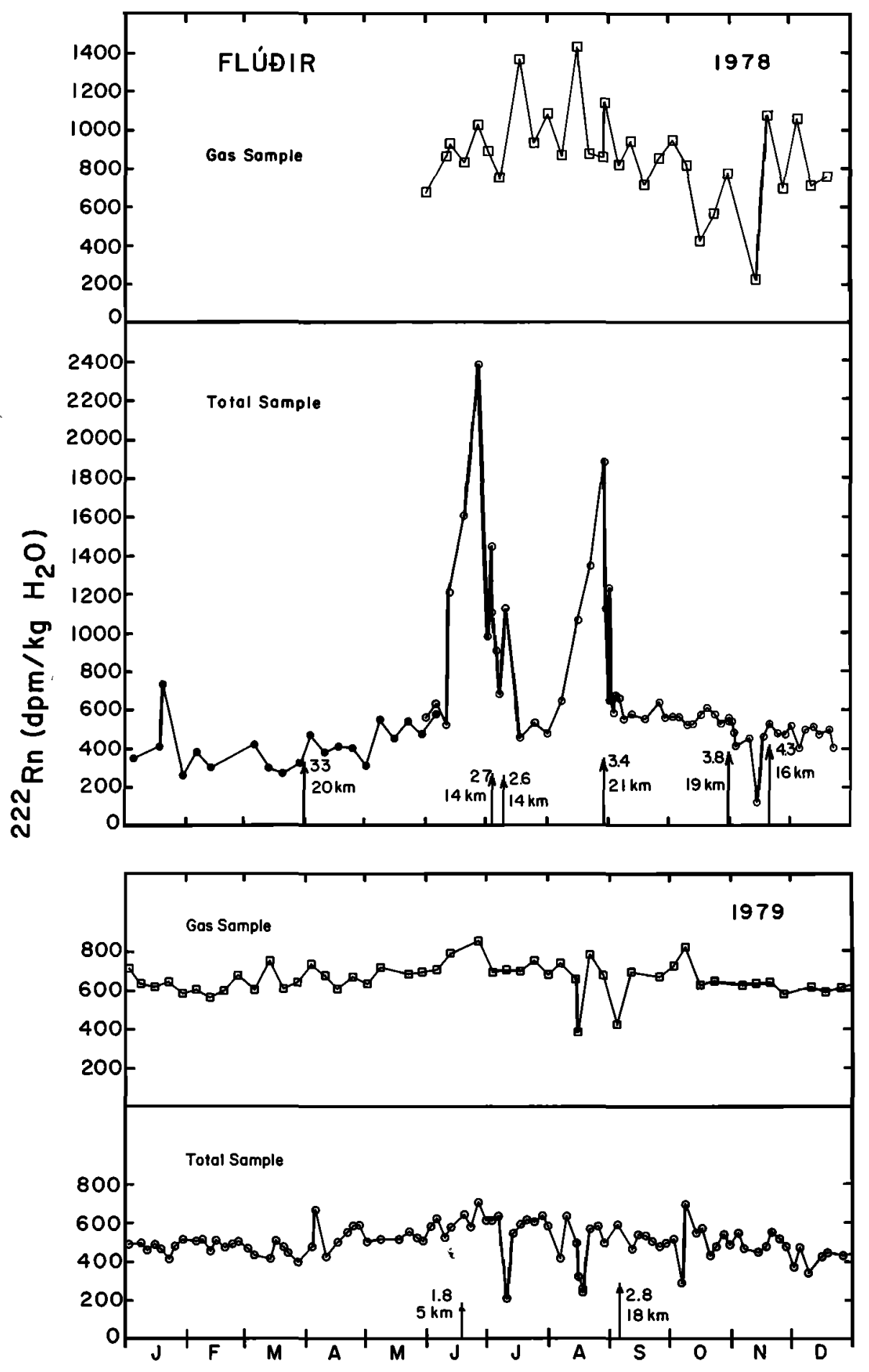

Fig. 6. Radon time series, total and gas sample, for 1978 and 1979 from sampling station Fludir. The arrow shows time of earthquake, the upper number its magnitude, and lower number approximate distance between epicenter and radon station.

total sample data. In the section on 'Sampling Methods' it was pointed out that for small earthquakes the two different samples need not show the same result. The anomalies that occurred in July and August were recognized as precursors prior to the respective earthquakes, but no predictions were issued. Both the radon content and the wellhead pressure showed a slight seasonal trend that was caused by the long term pattern of water usage. The more noticeable short term noise spikes in the total sample data that occurred in January 1978, July 1979, and August 1979, corresponded to an inadequate sampling method, erroneous sampling and maintenance of the well, respectively.

In Figure 7 radon data collected at Laugaland are presented. During 1978 the data were dominated by short term fluctuations, which coincided with a burst in local earthquake activity. Two events can be identified in the total sample data 


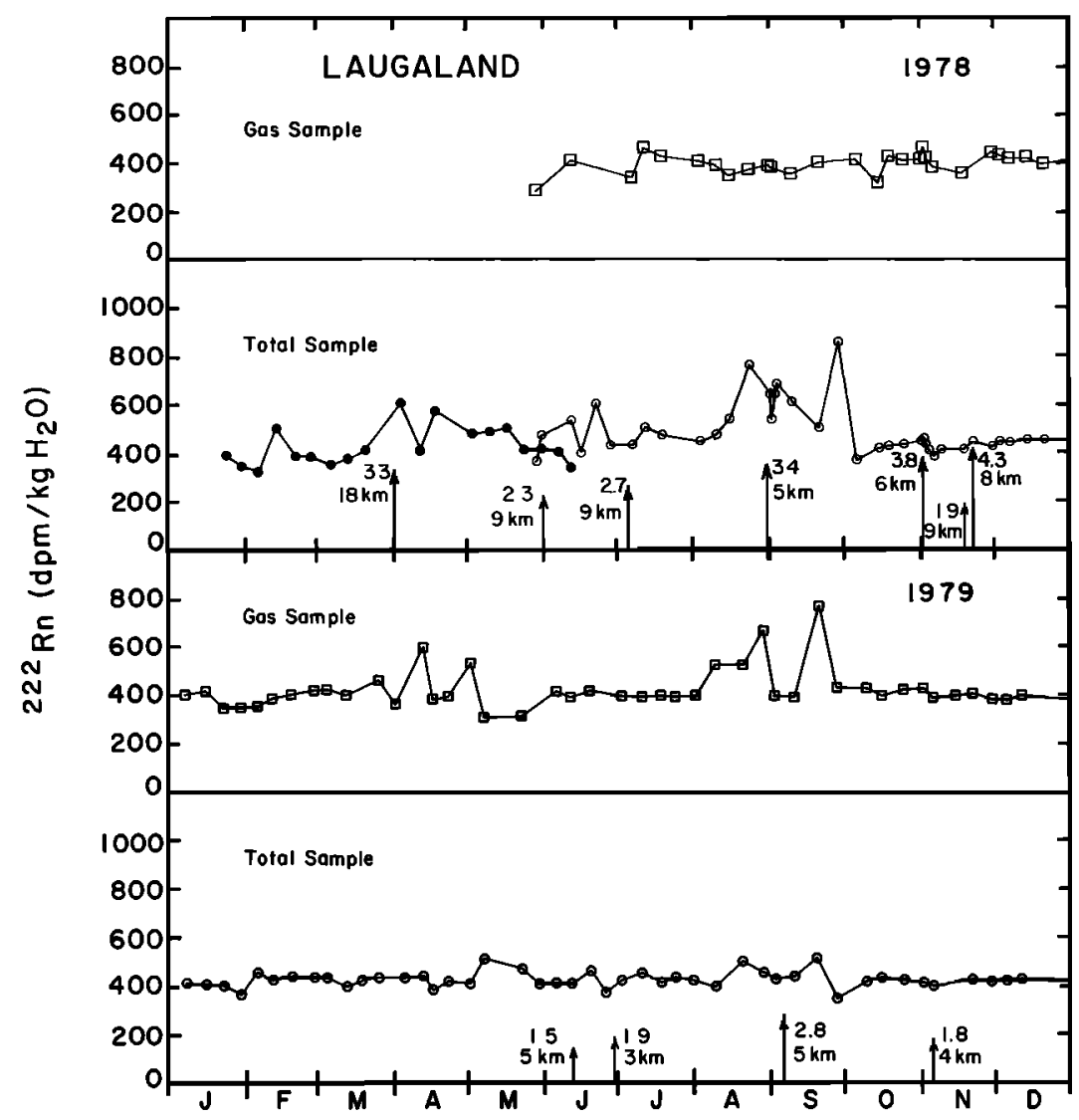

Fig. 7. Radon time series, total and gas sample, for 1978 and 1979 from sampling station Laugaland.

during 1978. A radon anomaly occurred prior to a $M=3.4$ earthquake in August and a false alarm was observed in late September. During 1979 only one anomaly was observed in the gas sample data. It was caused by an increase in the flux ratio of gas to water by a factor of ten. Although this anomaly may be earthquake related, it is not included in the analysis that follows because of its unusual origin.

Figure 8 displays total sample radon data from Kaldarholt, Hlemmiskeid, and Ormsstadir. Both Kaldarholt and Ormmsstadir showed rapid short term fluctuations during the burst in local earthquake activity that continued throughout 1978. At Kaldarholt these fluctuations made it impossible to identify any clear events in the data, even though two data points deviated more than two standard deviations from the yearly mean. One radon anomaly was observed at Kaldarholt in August 1979. The negative spike in July 1979 was presumed to be erroneous sampling, since the samples were drawn from a storage tank as described earlier. The data from Hemmiskeid showed no significant fluctuations during 1978, but two radon anomalies occurred in June and August 1979. At Ormmstadir the total sample data reflected an anomaly in October 1978. During 1979 the radon content at Ormmsstadir almost followed a straight line and no earthquakes occurred within the distance range of the station.

Observations of waterlevel from well 7 and total pumping rate from wells 8,9 , and 10 in the geothermal field at Selfoss were made available by G. K. Halldorsson (personal communication, 1980). Well 7 is located between wells 9 and 10 , about $20 \mathrm{~m}$ away from well 9 . These data as well as radon and chloride content for 1979 from well 9 are compared in the up- per half of Figure 9. The chloride data correlated with the waterlevel data, indicated increased seepage of cold surface groundwater with lowering of the watertable in the geothermal reservoir. This was also confirmed by a $3^{\circ} \mathrm{C}$ decrease in water temperature over a period of two months in late 1979 [Halldorsson, 1980]. The radon content, however, did not change, indicating that either the two types of water had the same radon content or the seepage occurred far enough away from the boreholes to allow equilibration of the mixture to the steady state radon signal of the aquifer.

Radon data from 1978 that were collected at Selfoss, well 9, and Oxnalaekur are shown in the lower half of Figure 9 to facilitate comparison. Two different mean and standard deviation values were calculated for 1978 total sample data from Selfoss, well 8 and well 9, respectively. During 1978 three false alarms were observed in the data from well 9. One false alarm occurred in February 1979. At that time the pumping rate in well 9 was reduced from $451 / \mathrm{s}$ to $351 / \mathrm{s}$ because the pump was taking in too much air with the water.

The change in radon observed at Oxnalaekur in late January and February and again in November and December 1978 was probably induced by changes in wellhead pressure. During the period of high radon, however, the pressure was low $\left(\sim 2 \mathrm{~kg} / \mathrm{cm}^{2}\right)$ and during the period of low radon the pressure was high $\left(\sim 4 \mathrm{~kg} / \mathrm{cm}^{2}\right)$. During periods of low wellhead pressure, the well mostly emitted a wet steam phase that explained this apparent increase in radon content and it should have been sampled as a high temperature geothermal well with a steam separator. These changes in wellhead pressure were probably user dependent, but they did not hamper the 

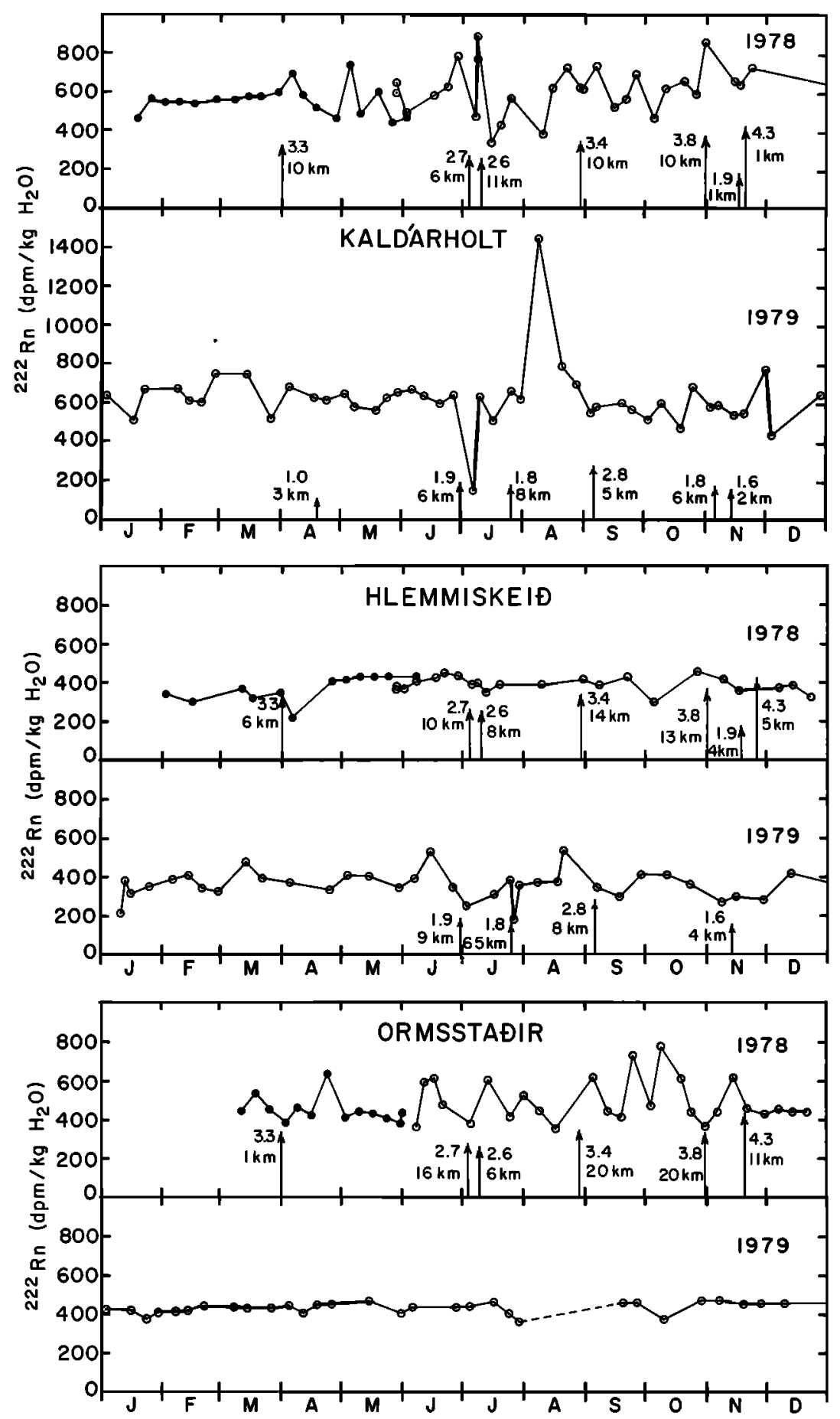

Fig. 8. Radon time series for 1978 and 1979 from sampling stations Kaldarholt, Hlemmiskeid, and Ormsstadir.

identification of possible radon anomalies prior to the two earthquakes that occurred within the distance range of the station.

In Figure 10 radon data from Dalvik and Hafralaekur in the TFZ are shown. One change in radon content that preceded local seismicity was identified at Hafralaekur in December 1979. False alarms occurred at Hafralaekur in February 1978 and Dalvik in September 1979. The false alarm observed at Dalvik was probably caused by mixing of water from shallower aquifers with the water from the main aquifer, since it coincided with a $30 \%$ increase in chloride content. The leakage between aquifers could have occurred as a response to long term drawdown of the water table. At Hafralaekur the sampling valve on the wellhead was moved to a new position in February 1978. An unusually low value observed in the total sample at Dalvik in December 1979 is not considered to be a false alarm since it is probably a result of leakage of radon from the sampling bottle during transit.

In summary, the radon time series contained nine possible precursory anomalies and seven false alarms. Fludir and 


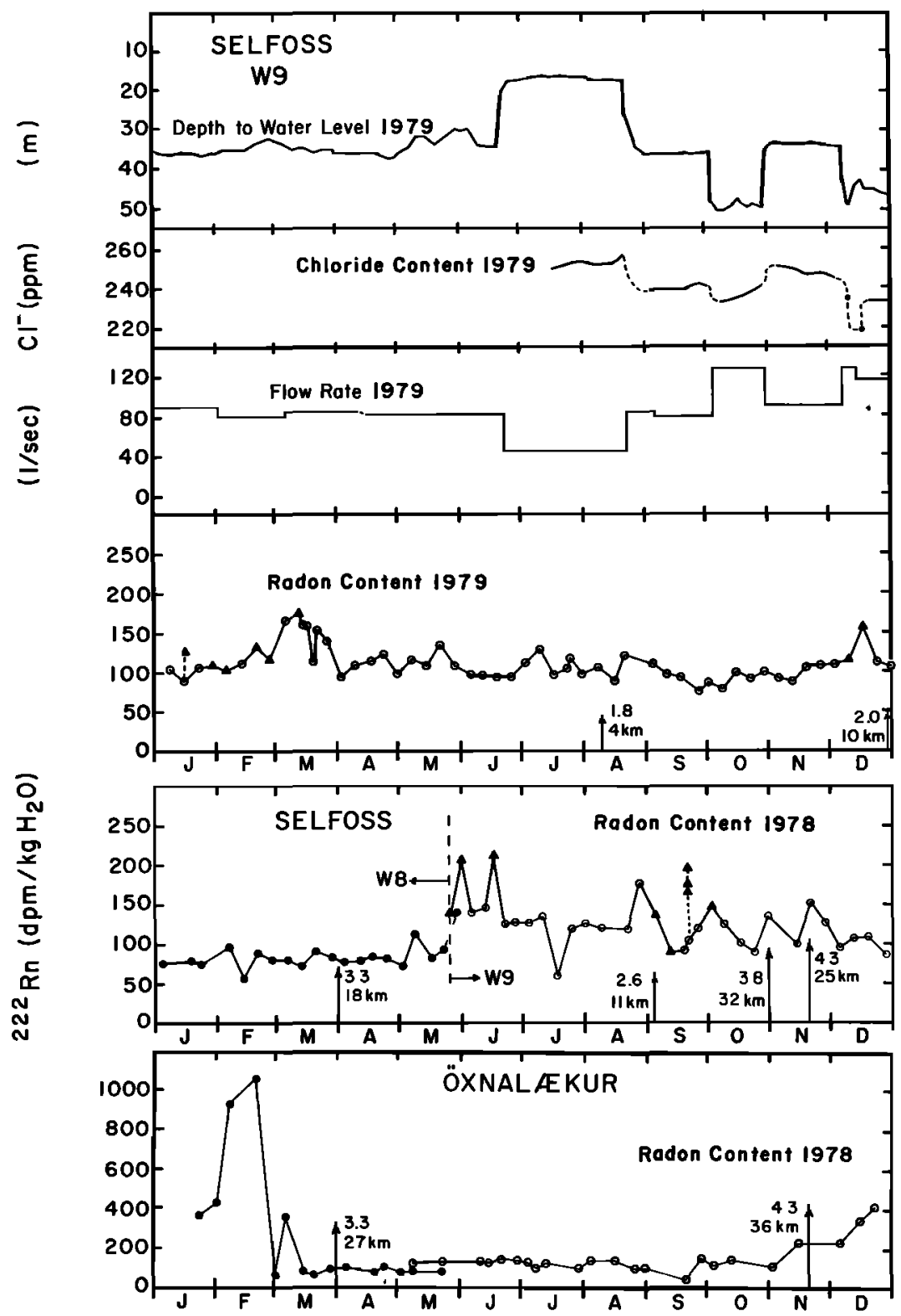

Fig. 9. Radon time series for 1978 and 1979 from sampling stations Selfoss and Oxnalaekur. Above chloride content of well 9 in fall 1979. Also shown water level and pumping rate at Selfoss, from Halldorsson [1980].

Hlemmiskeid showed the largest number of anomalies, three and two, respectively. Selfoss produced four false alarms, but no anomalies.

\section{ANALYSIS OF RADON DATA AND LOCAL SEISMICITY}

From 57 potential observations of long-term radon anomalies, the analysis of radon data and local seismicity resulted in nine different precursory radon anomalies and 48 cases of lack of anomalies. In two cases radon anomalies were observed in total and gas samples simultaneously. The respective earthquakes that were of magnitude 4.3 and 4.1 , were the largest ones observed during 1978 and 1979. In all other cases the earthquakes were smaller and the anomalies were expressed by an increase of radon only in the water phase.

The set of earthquakes of magnitudes greater than 2.0 that was available for correlation with the radon data was unfortunately too small to allow quantitative statistical testing of the correlation between the two. Several qualitative arguments, however, can be presented to support the assumption that there is a significant correlation between the observed radon anomalies and the respective earthquakes. Both the amplitude and the precursor time of the anomalies were in most cases defined by several data points and deviated significantly from the background noise level and the sampling interval used. All of the observed radon anomalies approached the baseline of the data near the time of the earthquake. Earthquakes rarely coincided in time with the rise of an anomaly. Two earthquakes out of seven were associated with two different anomalies. The empirical distance-magnitude relationship that was used to select the earthquakes, ensured that all earthquakes which could correlate with the radon data according to reports from the USSR and China were included. Thus the radon anomalies constituted significant deviations in the radon data that were observed to correlate in time with some of the earthquakes within the range of the respective station. 

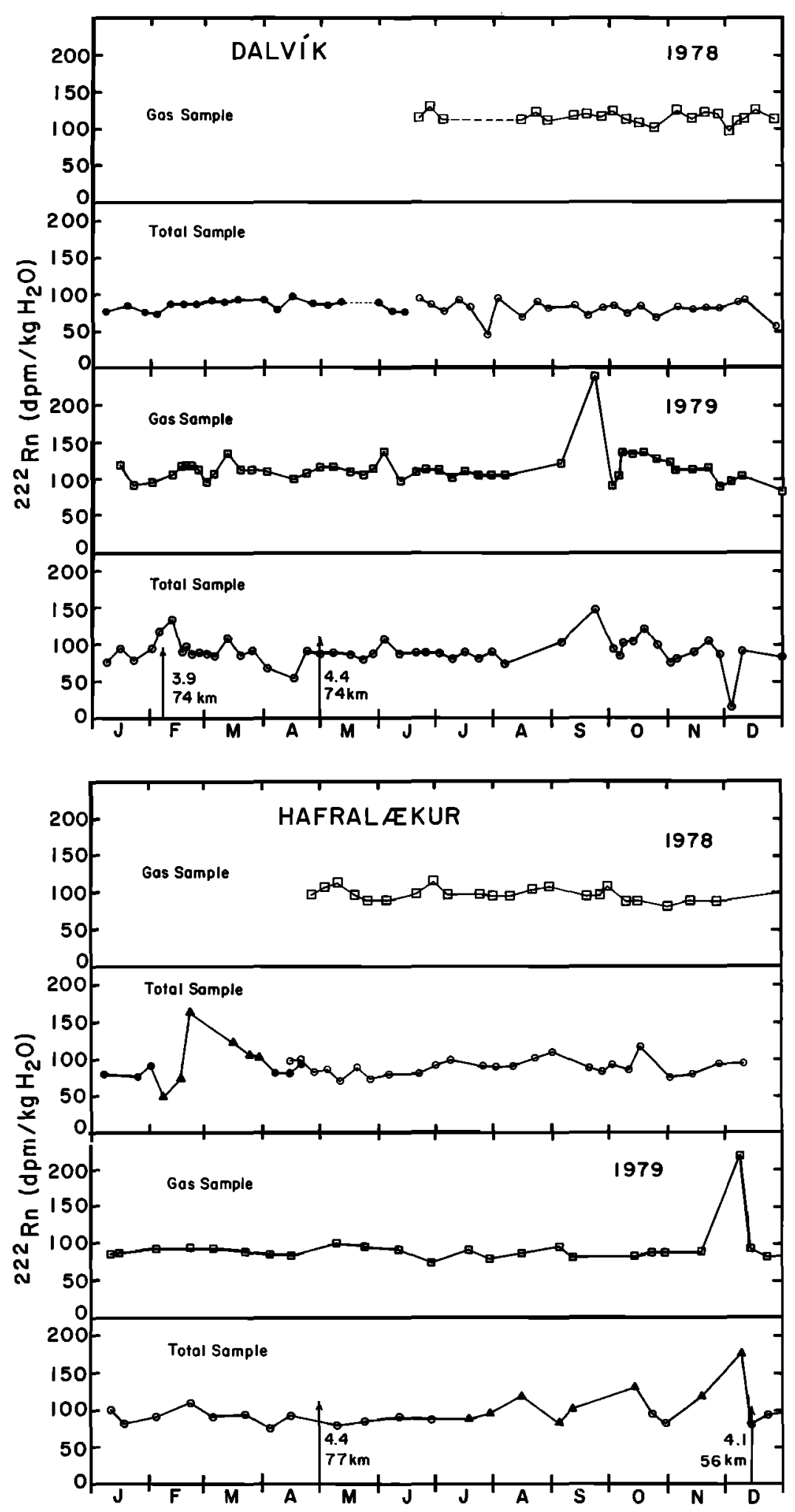

Fig. 10. Radon time series, total and gas sample, for 1978 and 1979 from sampling stations Dalvik and Hafralaekur.

To obtain a meaninful number for the probability of observing radon anomalies at all stations within the range of an earthquake according to rule 2 , the following must be taken into account. First, all earthquakes of magnitude equal to or greater than 1.0 were included in the analysis. If only earth- quakes of magnitude greater than 2.0 are included, the rate of failure decreases from 48 to 32 but also one successful anomaly must be dropped. Second, Selfoss, Oxnalaekur and Dalvik, never exhibited anomalous behavior prior to earthquakes. If they are excluded from the analysis, the failure rate de- 


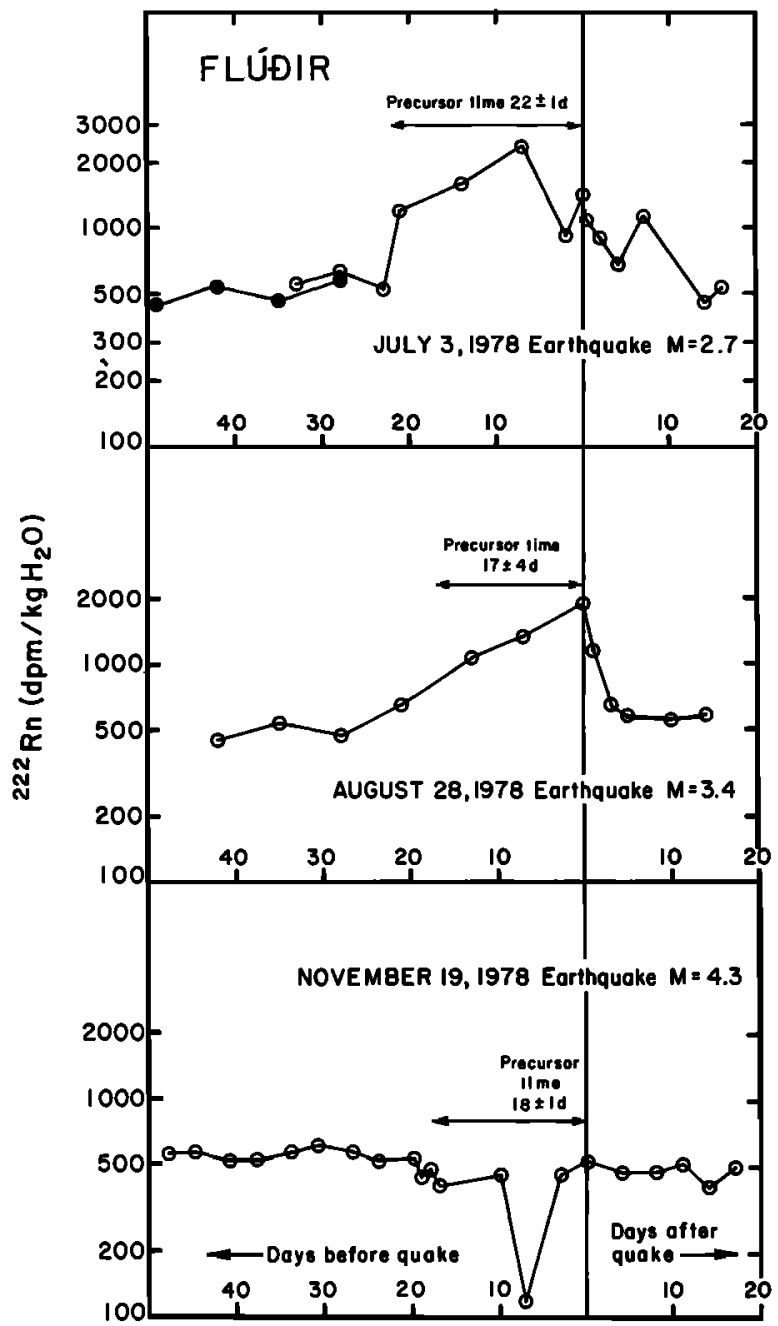

Fig. 11. A demonstration of how radon anomalies observed at sampling station Fludir were defined. The anomaly of November 19 could also have a duration of $8 \pm 2$ days; however, a duration of $18 \pm$ 1 day is also in agreement with the gas sample data.

creases from $32(M>2.0)$ to 22 . Therefore, the probability of observing anomalies at all relevant stations prior to an earthquake is about $30 \%$.

The probability of observing just one radon anomaly prior to an earthquake is considerably higher, or approximately 65\%. This result is based on the data in Table 3 where seven earthquakes out of a set of eleven were preceded by a radon anomaly, when earthquakes of magnitude greater than 2.0 are included. For earthquakes of magnitude less than 2.0, radon anomalies were rarely observed. This, however, could be an artifact in the data caused by the finite sampling frequency.

In the SISZ when only earthquakes of magnitude greater than 2.0 were included, five out of eight earthquakes were preceded by an anomaly at one or more stations. The only earthquake (number 1 in Table 3) of magnitude greater than 3.0 in the SISZ that was not preceded by an anomaly appeared to have an unusually deep hypocenter of between 5 and $17 \mathrm{~km}$ depth.

In Figure 2 all earthquakes in the SISZ that were preceded by one or two radon anomalies are marked with one or two arrows pointing towards the respective radon station. The radon stations are also marked with corresponding arrows such that a single arrow represents the first anomaly and a double arrow represents the second observed there (see also Table 3). The observations are insufficiently dense to form conclusions about the azimuthal relationship between radon anomalies and seismic events.

Only one anomaly was observed in the TFZ, even though three earthquakes occurred within range of a radon station. This result is not unexpected, when the complicated tectonic structure of the region is taken into account.

Figure 12 includes both anomalies (shown as shaded squares) and 'lack of anomalies' (shown as crosses) as observed at all stations within the range of each earthquake. The 'lack of anomalies' data points simply mean that an anomaly should have been observed according to rule 2 in the last section, but could not be identified in the relevant time series. The dashed line to the left is the rule 2 . The data plotted in Figure 12 indicate that the observed anomalies did not occur in the immediate vicinity of the epicenter. Also, there exists a weak trend in the data such that anomalies occurred farther away for earthquakes of larger magnitude. The amplitude of the anomalies did not seem to change systematically with distance, however. The ratio of the amplitude to the normal baseline value of radon content was highest at Fludir, about a factor of four, but varied from a factor of two down to less than a half at other stations. This implies that the probability of occurrence and the amplitude of a radon anomaly at a station depended more strongly on local conditions and earth-

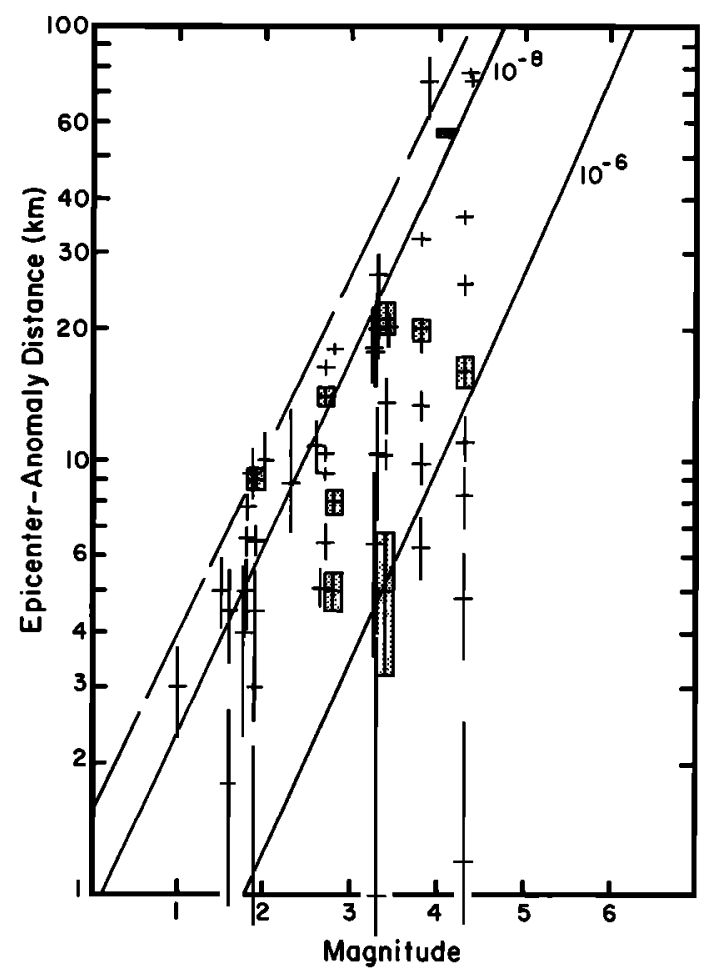

Fig. 12. Frequency of occurrence of radon anomalies in Iceland as a function of magnitude and distance from epicenter to radon station. The shaded squares are observed anomalies and crosses are failures to observe an anomaly. The error bars are the horizontal location errors of the earthquakes and assumed $\pm 1 / 10$ uncertainty in magnitude. The lines $10^{-8}$ and $10^{-6}$ are strain radii around an ellipsoid inclusion [from Dobrovolsky et al., 1979]. The dashed line is rule 2; see text. The earthquake shown beyond the dashed line is included since its epicentral location is poorly constrained. 
quake parameters than the distance from epicenter to radon station.

The aquiclude that divides the SISZ, as discussed previously, did not appear to affect the occurrence of radon anomalies, but the amplitudes of anomalies on the east side were larger than the ones on the west side. Figure 2 shows that the seismicity was higher on the east side of the aquiclude than on the west side. More earthquake data, however, are needed to draw firm conclusions about whether earthquakes on one side of the aquiclude are preferentially preceded by a radon anomaly.

The duration time of the observed radon anomalies or the precursor time interval in days is plotted against magnitude in Figure 13. The uncertainty assigned to each precursor time follows from the weekly sampling frequency. The sloping line to the right represents the precursor time-magnitude relationship found by Scholz et al. [1973] from a worldwide set of a variety of precursors. Their relationship was best constrained in the magnitude range from four to seven. The range of precursor time values found in this study shows a similar scatter as the data used by Scholz et al. [1973].

False alarms were recognized at Laugaland, Selfoss, Dalvik, and Hafralaekur. The false alarms never occurred at more than one station at a time. An attempt was made to correlate the false alarms to seismicity in the adjacent volcanic zones, but it proved to be unsuccessful.

\section{CONSTRAINTS ON THE ORIGIN OF THE RADON ANOMALIES}

The origin of the observed radon anomalies is mostly unknown. Certain constraints can be derived, however, from laboratory experiments, in situ permeability measurements, local geology, and knowledge about earthquakes. To make it as quantitative as possible, the discussion presented below refers frequently to data from the SISZ.

Measurements of the geothermal waters in the SISZ showed that the water contained negligible amounts of radium. Therefore the radon in the geothermal waters is presumed to originate in the rock matrix of the aquifer. Laboratory studies of radon emanation from rocks as a function of particle size of the rock have been carried out by Andrews [1977]. His results showed that the radon release is proportional to $1 / \sqrt{d}$, where $d$ is the particle diameter. Recoil of radon into crystal imperfections or grain boundaries which allows fast diffusion into water filled cracks and pores can account for this result. The ratio of radon emanated into the water to radon generated in the rock is thus a complicated function of the radium distribution, crystal imperfections, grain boundaries, rock structure, and applied stress field. Since the radon content of pore water in a crack depends on the emanating power of the rock and the ratio of surface area to the volume of the crack, locally different sets of cracks can contain pore water of different radon content. Once the radon enters the aquifer, it is transported mainly by convective motion of the water. Therefore, in simplistic terms, to create a radon anomaly that is related to changes in rock properties, either the crack structure, the emanating power of the rock, or the transport velocity of the water from the radon source to the surface have to change. It is also possible to have radon events that are induced in the aquifer water by, for example, the formation of bubbles. Such events will probably not be useful as an earthquake precursor since in most cases of this study they were false alarms.

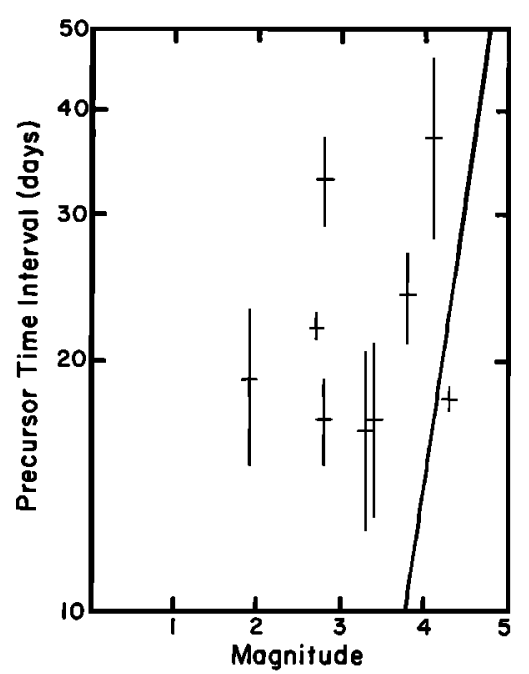

Fig. 13. The duration time of observed radon anomalies in Iceland plotted as a function of magnitude. Error bars are determined by discrete sampling frequency (see Table 3). Sloping line is from Scholz et al. [1973].

Radon $\left({ }^{222} \mathrm{Rn}\right)$ has a half-life of 3.8 days, which effectively means that an anomaly can spend at most 20 days travelling from a source to a monitoring well. If the travel time is longer, the anomaly will be totally attenuated since radon decays exponentially with time to its daughter isotopes. The flow velocity of groundwater is determined by the rock permeability and regional hydraulic gradient which in some cases can be modified by localized withdrawal of water, for example, at geothermal wells. Fortunately, several experimental measurements of in situ transmissivity or hydraulic conductivity are available for the Selfoss field and other geothermal fields of similar geological and geophysical character as the SISZ [Thorsteinsson, 1975; Halldorsson, 1980]. These data can be used to calculate the intrinsic permeability of the aquifer rock or the regional flow velocity of groundwater. Values of intrinsic permeability found by Thorsteinsson [1975] range from 4 to 14 darcies. Using the in situ hydraulic data and following Arnason [1976] by assuming a hydraulic gradient in the SISZ of $10^{-2}$ and the validity of Darcy's law, flow velocities in the range from $0.02 \mathrm{~m} /$ day to $1.6 \mathrm{~m} /$ day are obtained. The porosity was assumed to be $20 \%$ based on data presented by Fridleifsson [1975]. These values of flow velocity demonstrate that the regional hydraulic gradient is at most capable of transporting a radon anomaly a distance of $32 \mathrm{~m}$ in 20 days. A typical flow rate of water from a geothermal well, for example at Selfoss is $40 \mathrm{l} / \mathrm{s}$. If this water is drawn from a $10 \mathrm{~m}$ tall cylinder of rock with $20 \%$ porosity, the resulting cylinder radius, that enables a constant rate of pumping for 20 days, is $105 \mathrm{~m}$. This is about three times larger than the previous distance. Hence, the observed radon anomalies cannot be hydraulically transported over large distances.

Large-scale changes in either permeability or hydraulic gradient caused by precursory phenomena should manifest themselves through changes in water level in local wells. No water level changes on the order of meters or large wellhead pressure changes were reported at the time of a radon anomaly or the respective earthquake at any of the stations. Therefore, it is reasonable to conclude that the flow velocity of the groundwater remained stable within an order of magnitude.

The earthquakes that were preceded by radon anomalies in 
the SISZ had magnitudes ranging from 2 to 4.3 which roughly corresponds to slip on fault planes with dimensions between $0.3 \mathrm{~km}$ and $7 \mathrm{~km}$ [Wyss and Brune, 1968]. Most of the radon anomalies were observed 10 to $20 \mathrm{~km}$ away from the epicenter (see Figure 12) which is equivalent to a distance of about 5 to 10 fault lengths.

One way to estimate the size of an earthquake preparation zone, is to use mathematical modelling. Dobrovolsky et al. [1979] presented a model that treats the earthquake preparation zone or the focal region as a solid soft inclusion in a surrounding elastic matrix. The model has an analytical solution and can include anisotropy and up to $30 \%$ heterogeneity of the inclusion. Assuming 30\% heterogeneity of the inclusion and an unknown stress direction, a radial strain field surrounding the inclusion can be calculated for different size earthquakes. In Figure 12 the two parallel lines correspond to the maximum distance of a strain field of $10^{-6}$ and $10^{-8}$, respectively. Thus, according to this mathematical model, the majority of the radon anomalies were observed in regions that experienced an applied strain field of $10^{-6}$ to $10^{-8}$. No experimental evidence is available, however, on the size of a strain field needed to sustain a radon anomaly.

Based on the travel time arguments presented above and the large distance between the epicenter and the monitoring well relative to the size of the forthcoming rupture zone, it is suggested tentatively that the observed radon anomalies resulted from changes in the immediate vicinity of the wells, rather than at the distant focal region. To accomplish this, it is necessary to assume that changes in stress or strain are propagated from the forthcoming rupture zone to the radon station. These changes must then lead to variations in the porosity, emanating power or velocity of the local groundwater near the observing station. In light of these suggestions, the two different cases, Selfoss and Fludir, are discussed below.

It can be clearly seen from Figure 9 that steady state conditions existed at Selfoss such that the radon concentration, $C$, was independent of flow rate and was given by

$$
C=E / \phi
$$

where $E$ is the radon emanating power of the rock and $\phi$ the porosity [Andrews, 1977]. To create a change in radon content at Selfoss either $E$ or $\phi$ has to change. Large scale changes in porosity have to be accompanied by large waterlevel changes to conserve the mass of water in the reservoir. A $50 \%$ increase in radon content, if sustained by changes in porosity, requires removal of a third of the water volume in the reservoir. The emanating power of the rock usually ranges from $10 \%$ to $0.1 \%$. It mainly depends on mineral composition and as mentioned above, it varies as $1 / \sqrt{d}$ where $d$ represents particle diameter. Since the porosity is proportional to $d^{b}$, the emanating power can only be a weak function of porosity. At low strain levels, it is therefore reasonable to assume that the porosity and the emanating power will stay almost constant. Thus the four observed false alarms at Selfoss might not be related to changes in rock properties but rather to changes in the water contained in the reservoir. The radon content of the water can be changed, as discussed earlier, through heterogeneous formation of bubbles in the water. Formation of bubbles depends on the water turbulence around the well bore at depth and on the type of flow (laminar, layered or turbulent) in the well pipes near the sampling valve. A way to distinguish bubble formation from a real radon anomaly is to collect a series of total samples within a few minutes or to collect both a total and a gas sample. The formation of bubbles is called heterogeneous, since it was observed to create a greater than $50 \%$ deviation in radon content in 0.5 liter samples (total samples) collected at Selfoss in September 1978 and January 1979 as shown in Figure 9. A similar situation as at Selfoss might be prevailing also at the sampling station, Dalvik. All other stations are operated at much lower flow rates and thus formation of bubbles should not be a major effect.

The sampling station, Fludir, is peculiar in several respects. First, it is the only station that showed seasonal changes in radon content associated with a similar change in well head pressure. Second, in 1978 it produced two spectacular radon anomalies. Third, Fludir is located close to acidic intrusives that are presumably rich in radioactive minerals. The short rise time of the anomalies observed at Fludir can be explained by increases in flow velocity of a radon rich liquid caused by closure or opening of existing sets of cracks. Unfortunately, no pressure or flow rate gauges had been installed prior to the periods of anomalous radon emission in 1978. Mixing of liquids of different radon content can also create anomalies with short rise time, but these might be accompanied by changes in temperature or chloride content. It is less likely that inelastic crack growth was taking place since the responsible stress or strain field that originated in the focal region, decreased rapidly with distance. Furthermore, closure and opening of cracks constitute a discrete process that through laminar fluid flow can lead to rapid fluctuations in the radon data as observed during 1978 at some other stations in the SISZ.

Thus, wells that are utilized at a moderate flow rate are less likely to show false alarms than wells utilized at high flow rates. Wells situated close to rock formations rich in radioactive minerals may be more likely to show anomalies than others.

\section{Discussion AND Conclusions}

This report presents two years of weekly radon data from nine different sampling stations in the SISZ and the TFZ in Iceland. The choice of sampling frequency of one week was based on the expected precursor time interval from the model of dilatancy diffusion [Scholz et al., 1973], radon data reported by Antsilevich [1971] and purely practical and economical considerations. If the dilatancy model is applicable in this case, a sampling frequency of one week should be enough to catch precursors related to earthquakes of magnitude three or greater. Antsilevich [1971] reported several radon anomalies with relative amplitudes of $23 \%$ that lasted from three to eight days and preceded earthquakes of magnitudes between 3.0 and 3.5. This study presents the results of correlating weekly radon data with earthquakes of magnitudes between 1.0 and 4.3. The observed anomalies lasted from 17 to 37 days. Most of the anomalies were therefore defined by several data points. The relative amplitude of the anomalies that ranged from $40 \%$ to $380 \%$ can be contrasted with the short term background noise level of the data which was found to be less than $10 \%$ at most stations. Thus weekly sampling frequency appeared to be quite adequate to study radon anomalies related to small local earthquakes.

It is possible that short term radon anomalies that last for a few hours up to a few days also occur in Iceland. To study these in an effective way, instruments that monitor radon continuously at the wellhead will be needed. Such an instrument (as used by Wakita et al. [1980]) was purchased from Japan 
and has been in operation at Fludir since August 1980. No earthquakes of magnitude greater than 2.0 occurred between August and December 1980 in the SISZ and the continuous data show that the radon content at Fludir has remained stable within a few percent.

Even though radon anomalies were picked after the occurrence of the earthquakes, there existed many cases of failure to observe anomalies and a few cases of false alarms. Two earthquakes of magnitude 3.3 and 4.3 occurred directly below the radon sampling station at Ormsstadir and Kaldarholt, respectively, but neither station showed any precursory changes. These observations suggest that the radon earthquake precursors depend on the parameters of the earthquake and can only be observed under very special conditions. As discussed previously, such conditions certainly exist in the SISZ. The sampling station Fludir is located close to a volcanic complex of acidic rocks that could be a radon rich source, the local hydrology is favorable to fluid flow through these formations. Other stations farther away from the volcanic complex seem to be only capable of sustaining low $(<100 \%)$ amplitude radon anomalies. Furthermore, stations that sample water from heavily fractured rock close to the volcanic zone appear to be less likely to show radon anomalies than the ones situated in older rock. Fludir, however, did not record all earthquakes that occurred within its distance range. Therefore earthquake parameters such as depth, focal mechanism, and stress drop have to be taken into account.

The false alarms were not unexpected, since besides being perturbed by local earthquakes, the geothermal reservoirs were often disturbed by actions related to their exploitation. Frequent shifts in water table sometimes induced seepage between aquifers and thus fluid mixing or variable water degassing in the well plumbing. Turbulence in the water caused by the pump can also lead to degassing. Chloride data may prove useful for identifying seepage between aquifers as demonstrated at Selfoss and Dalvik. The flux ratio between gas and water allows identification of variable degassing. In general, however, it has not been established whether these parameters remain stable or change prior to earthquakes. In at least one case, at Laugaland, the flux ratio was observed to change prior to an earthquake.

Future efforts in Icelandic radon studies should concentrate on decreasing the high rate of failure to observe anomalies and the occurrence of false alarms through a better understanding of the relationship between radon anomalies and earthquakes. One way to approach this problem would be to correlate parameters such as earthquake depth, focal mechanism, and stress drop with rise time and relative peak values of radon anomalies. Unfortunately, during this study of the SISZ the local seismic network was not dense enough to provide the earthquake data and the intermittent sampling of radon data was inadequate to provide good temporal coverage of radon anomalies.

In conclusion, radon anomalies preceded five out of eight local earthquakes in the SISZ with magnitudes ranging from 2.0 to 4.3. To detect radon anomalies with a similar success rate in the future and to be able to estimate magnitude and origin time of future earthquakes, weekly data from a network of at least seven stations spaced 10 to $15 \mathrm{~km}$ apart will be needed. The results of this study also indicate that radon anomalies might occur prior to moderate size or large earthquakes that are expected to occur in the next decades in the SISZ based on historical data [Bjornsson, 1975].
Acknowledgments. This project is a cooperative effort between scientists at LDGO and the Science Institute, University of Iceland. The LDGO part of the effort was partly funded by the U.S. Geological Survey contract 14-08-001-17726. Financial support, which was provided by the Sergievsky Charitable Trust during the initial stages of this project, is sincerely acknowledged. The Science Institute made laboratory space available for the equipment that is used to analyze the samples. Gudbjorg Aradottir has analyzed nearly every sample and taken care of the daily routine running of the project in Iceland; without her efforts, the results of this project would have been much diminished. Sigurdur Emil Palsson participated in the summer field work and maintained the radon equipment in our absence. We owe special thanks to a group of nine volunteers who carried out the weekly sampling. Their contribution has made this logistically difficult project practically possible. Gillian Fougler and Bryndis Brandsdottir provided us with up to date accounts of the local seismicity. We thank John Lupton and Harmon Craig of the Scripps Institution of Oceanography for analysis of the He and gas data presented in Table 2. We are grateful to Wallace S. Broecker, Lynn R. Sykes, David Simpson, Sveinbjom Bjornsson, and Bragi Amason for their stimulating comments and suggestions. We thank Lynn R. Sykes, Wallace $S$. Broecker, Roger Bilham, and Pall Einarsson for their critical reviews of the manuscript. All the drawings were done by Patricia Catanzaro, and Mary Anne Avins skillfully typed the manuscript. Lamont-Doherty Geological Observatory contribution 3134.

\section{REFERENCES}

Andrews, J. N., Radiogenic and inert gases in groundwater,-in Proceedings of the Second International Symposium on Water-Rock Interaction, pp. I334-342, 1977.

Antsilevich, M. G., An attempt to forecast the moment of origin of recent tremors of the Tashkent earthquake through observations of the variation of radon, Izv. Akad. Nauk Uzb. SSR, 188-200, 1971.

Arnason, B., Groundwater systems in Iceland traced by Deuterium, Soc. Sci. Islandica, 42, 236 pp., 1976.

Arnorsson, S., Geochemical studies of thermal waters in the southern lowlands of Iceland, Spec. Issue Geotherm, 2, 547, 1970.

Aronson, J. L., and K. Saemundsson, Relatively old basalts from structurally high areas in central Iceland, Earth Planet. Sci. Lett., 28, 83-97, 1975.

Asimov, M. S., Zh. S. Yerzhanov, K. Ye. Kalmurzaev, M. K. Kurbanov, G. A. Mavlyanov, S. Kh. Negmatullaev, I. L. Nersesov, and V. I. Ulomov, The state of earthquake prediction research in the Soviety republics of central Asia, (in Russian), in International Symposium on Earthquake Prediction, Rep. III-12, Unesco, Paris, 1979.

Bjornsson, A., G. Johnsen, S. Sigurdsson, G. Thorbergsson, and E. Tryggvason, Rifting of the plate boundary in North Iceland 19751978, J. Geophys. Res., 84, 3029-3038, 1979.

Bjornsson, S., Earthquakes in Iceland (in Icelandic), Natturufraedingurinn, 45(2), 110-133, 1975.

Bjornsson, S., and P. Einarsson, Seismicity of Iceland, in Geodynamics of Iceland and the North Atlantic Area, edited by L. Kristjansson, D. Reidel, Hingham, Mass., 1974.

Broecker, W. S., The application of natural radon to problems in ocean circulation, in Symposium on Diffusion in Oceans and Fresh Waters, edited by T. Ichiye, pp. 116-145, Lamont-Doherty Geological Observatory, Palisades, New York, 1965.

D'Amore, F., Radon-222 survey in Larderello Geothermal Field, Italy, 1, Geothermics, 4, 96-108, 1976.

Dobrovolsky, I. P., S. I. Zubkov, and V. I. Miachkin, Estimation of the size of earthquake preparation zones, Pure Appl. Geophys., 117, 1025-1044, 1979.

Einarsson, P., Relative location of earthquakes within the Tjornes Fracture Zone, Soc. Sci. Islandica, V, 45-60, 1976.

Einarsson, P., Seismicity and earthquake focal mechanisms along the Mid-Atlantic plate boundary between Iceland and the Azores, Tectonophysics, 55, 127-153, 1979.

Fridleifsson, I. B., Lithology and structure of geothermal reservoir rocks in Iceland, in Proceedings of the Second U.N. Symposium on Development and Use of Geothermal Resources, pp. 371-376, U.S. Government Printing Office, Washington, D. C., 1975.

Halldorsson, G. K., Results from hydraulic experiments in the geothermal field at Selfoss, southern Iceland (in Icelandic), professional paper, 27 pp., Nat. Energy Authority of Iceland, Reykjavik, 1980. 
Liu, P. L., D. K. Wan, and T. M. Wan, Studies of forecasting earthquakes in the light of the abnormal variations of $R n$ concentrations in groundwater, Acta Geophys. Sinica, 18, 279-283, 1975.

Palmason, G., Kinematics and heat flow in a volcanic rift zone, with application to Iceland, Geophys. J. R. Astron. Soc., 33, 451-481, 1973.

Raleigh, B., G. Bennett, H. Craig, T. Hanks, P. Molnar, A. Nur, J. Savage, C. Scholz, R. Turner, and F. Wu, Prediction of the Haicheng earthquake, Eos Trans. AGU, 58, 236-272, 1977.

Saemundsson, $\mathbf{K}$., Interglacial lava flows in the lowlands of southern Iceland and the problem of two-tiered columnar jointing, Jokull. $20,62-76,1970$.

Saemundsson, $K$., Evolution of the axial rifting zone in northern Iceland and the Tjornes Fracture Zone, Geol. Soc. Am. Bull., 85, 495504, 1974.

Scholz, C. H., L. R. Sykes, and Y. P. Aggarwal, Earthquake prediction: A physical basis, Science, 181, 803-810, 1973.

Stefansson, V., and S. Arnorsson, A comparative study of hot-water chemistry and bedrock resistivity in the southern lowlands of Iceland, National Energy Authority, Iceland, in Proceedings of the Second U.N. Symposium on Development and Use of Geothermal Resources, pp. 1207-1216, U.S. Government Printing Office, Washington, D. C., 1975.

Suzuki, Z., On the Chinese prediction of earthquakes, Chin. Geophys., I, 393-425, 1978 .

Thorsteinsson, Th., The redevelopment of the Reykir hydrothermal system in S.W. Iceland, in Proceedings of the Second U.N. Sym- posium on Development and Use of Geothermal Resources, pp. 21732180, U.S. Government Printing Office, Washington, D. C., 1975.

Tryggvason, E., Seismicity, earthquake swarms, and plate boundaries in the Iceland region, Bull. Seismol. Soc. Am., 63(4), 1327-1348, 1973.

Ulomov, V. I., and B. Z. Mavashev, Forerunners of the Tashkent earthquakes, Izv. Akad. Mauk Uzb. SSR, 188-200, 1971.

Wakita, H., Earthquake prediction and geochemical studies in China, Chin. Geophys., 1, 443-457, 1978.

Wakita, H., Y. Nakamura, M. Noguchi, and T. Asada, Radon anomaly-Possible precursor of the 1978 Izu-Oshima-Kinkai earthquake, Science, 207, 882, 1980.

Wang, C. Y., Some aspects of the Tangshan (China) earthquake of 1976, Chin. Geophys., I, 157-172, 1978.

Weast, R. C. (Ed.), Handbook of Chemistry and Physics, 58th ed., Chemical Rubber Co., Cleveland, Ohio, 1977-1978.

Wood, D. A., J.-L. Joron, M. Treuil, M. Norry, and J. Tarney, Elemental and $\mathrm{St}$ isotope variations in basic lavas from Iceland and the surrounding ocean floor, Contrib. Mineral. Petrol., 70, 319-339, 1979 .

Wyss, M., and J. W. Brune, Seismic moment, stress, and source dimensions for earthquakes in the California-Nevada region, $J$. Geophys. Res., 73, 4681-4694, 1968.

(Received July 21, 1980;

revised December 22, 1980; accepted February 10, 1981.) 